\title{
Effect of calcium source on structure and properties of sol-gel derived bioactive glasses
}

\author{
Bobo Yu ${ }^{1}$, Claudia A. Turdean-Ionescu ${ }^{2}$, Richard A. Martin ${ }^{3}$, Robert J. Newport ${ }^{4}$, John V. \\ Hanna $^{2}$, Mark E. Smith ${ }^{2,5}$, Julian R. Jones ${ }^{1}$ \\ ${ }^{1}$ Department of Materials, Imperial College London, London, SW7 2AZ, UK \\ ${ }^{2}$ Department of Physics, University of Warwick, Coventry, CV4 7AL, UK
}

${ }^{3}$ School of Engineering \& Applied Science and Aston Research Centre for Healthy Ageing, Aston University, Birmingham, B4 7ET, UK

${ }^{4}$ School of Physical Science, University of Kent, Canterbury, CT2 7NH, UK

${ }^{5}$ Vice-Chancellor's Office, University House, Lancaster University, LA1 4YW, UK.

KEYWORDS: bioactive glass; biomaterials; sol-gel; inorganic/organic hybrids; calcium methoxyethoxide 


\section{ABSTRACT}

The aim was to determine the most effective calcium precursor for synthesis of sol-gel hybrids and for improving homogeneity of sol-gel bioactive glasses. Sol-gel derived bioactive calcium silicate glasses are one of the most promising materials for bone regeneration. Inorganic/organic hybrid materials, which are synthesized by incorporating a polymer into the sol-gel process, have also recently been produced to improve toughness. Calcium nitrate is conventionally used as the calcium source but it has several disadvantages. Calcium nitrate causes inhomogeneity by forming calcium-rich regions and it requires high temperature treatment $\left(>400{ }^{\circ} \mathrm{C}\right)$ for calcium to be incorporated into the silicate network. Nitrates are also toxic and need to be burnt off. Calcium nitrate therefore cannot be used in the synthesis of hybrids as the highest temperature used in the process is typically $40-60{ }^{\circ} \mathrm{C}$. Therefore, a different precursor is needed that can incorporate calcium into the silica network and enhance the homogeneity of the glasses at low (room) temperature. In this work, calcium methoxyethoxide (CME) was used to synthesize solgel bioactive glasses with a range of final processing temperatures from 60 to $800{ }^{\circ} \mathrm{C}$. Comparison is made between the use of CME and calcium chloride and calcium nitrate. Using advanced probe techniques, the temperature at which $\mathrm{Ca}$ is incorporated into the network was identified for $70 \mathrm{~S} 30 \mathrm{C}\left(70 \mathrm{~mol} \% \mathrm{SiO}_{2}, 30 \mathrm{~mol} \% \mathrm{CaO}\right)$ for each of the calcium precursors. When $\mathrm{CaCl}_{2}$ was used, the $\mathrm{Ca}$ did not seem to enter the network at any of the temperatures used. In contrast, $\mathrm{Ca}$ from $\mathrm{CME}$ entered the silica network at room temperature, as confirmed by XRD,

${ }^{29}$ Si Magic Angle Spinning Nuclear Magnetic Resonance spectroscopy and dissolution studies. CME should be used in preference to calcium salts for hybrid synthesis and may improve homogeneity of sol-gel glasses. 


\section{Introduction}

Bioactive glasses bond with bone and are osteogenic ${ }^{1}$. However they are brittle, therefore hybrids are being developed with the aim of introducing toughness while maintaining the bioactive properties of the glass ${ }^{2,3}$. The bond with bone is thought to be due to their reaction with body fluid, which results in the formation of a hydroxy carbonate apatite (HCA) surface layer on the glass ${ }^{4}$. The first sol-gel bioactive glasses were prepared in the early 1990 s for bone regeneration ${ }^{5}$. The inherent nanoscale porosity of the sol-gel process significantly increases the surface area of these glasses ${ }^{6}$, which enhances the rates of apatite phase formation and bone bonding, together with controlled degradation/resorption properties. Foaming of sol-gel solutions has been performed to produce three-dimensional (3D) scaffolds that provide an interconnected macroporous network for cell migration, vascularization and bone ingrowth ${ }^{7,8}$. The foaming process uses a surfactant to stabilize the air bubbles and produce pores and hydrofluoric acid (HF) as a catalyst for rapid gelation of the silica network.

In a sol-gel glass a silica network forms by a condensation reaction under constant stirring ${ }^{9-11}$. Inhomogeneity in the structure appears when using the conventional $\mathrm{Ca}\left(\mathrm{NO}_{3}\right)_{2} \bullet 4 \mathrm{H}_{2} \mathrm{O}$ source for calcium. Lin et al. reported Ca-rich regions at the edges of large monoliths ${ }^{12}$. This is due to the $\mathrm{Ca}\left(\mathrm{NO}_{3}\right)_{2}$ being soluble in the pore liquor (the by-product of the condensation reaction) during the gelation and aging stages. This liquid is then expelled out of the gel due to the shrinkage. During drying, the pore liquor evaporates leaving $\mathrm{Ca}\left(\mathrm{NO}_{3}\right)_{2}$ deposits on the outer parts of the monolith. The calcium only enters the silicate network above $400{ }^{\circ} \mathrm{C}^{13-14}$ by diffusion above this temperature, but can only diffuse a limited distance during thermal stabilization ${ }^{14}$. In foams, 
where diffusion distances into the struts are short, homogeneity is improved, although a calcium distribution can be observed using synchrotron X-ray microtomography ${ }^{15}$. Strontium ions are thought to be beneficial for patients with osteoporosis and strontium has been introduced into the sol-gel glass composition using strontium nitrate, therefore $\mathrm{Sr}$ distribution may also be affected by diffusion distances and the type of precursor ${ }^{16}$. One aim of this work is to improve the homogeneity of calcium in sol-gel glass monoliths.

In order to induce toughness in sol-gel glasses, inorganic/organic hybrids that have interpenetrating networks of silica and biodegradable polymers can be synthesized. Hybrids are synthesized by introducing a polymer into the sol-gel process so that the silica network and polymer form interpenetrating networks at the nanoscale ${ }^{3,17-19}$. While calcium nitrate has been used in hybrid synthesis ${ }^{20}$, it did not enter the network during processing at the lower temperatures ${ }^{14}$ and is therefore not an ideal calcium precursor.

Since calcium is intrinsic to the bioactivity of the sol-gel glasses, there is a need to find an alternate $\mathrm{Ca}$ precursor that will introduce $\mathrm{Ca}$ into the silica network at room temperature, improving the homogeneity of sol-gel derived bioactive glasses and allowing hybrid synthesis ${ }^{1}$. One option is an alternative calcium salt with less toxic by-products, e.g. calcium chloride ${ }^{18,21}$ or calcium acetate. Another option is to use a calcium alkoxide, such as calcium methoxyethoxide (CME). Pereira et al. were the first to use CME to synthesize sol-gel derived bioactive glasses, synthesizing three compositions in the $\mathrm{CaO}-\mathrm{P}_{2} \mathrm{O}_{5}-\mathrm{SiO}_{2}$ system; $\mathrm{S} 60\left(60 \% \mathrm{SiO}_{2}, 36 \% \mathrm{CaO}\right.$ and $\left.4 \% \mathrm{P}_{2} \mathrm{O}_{5}\right), \mathrm{S} 70\left(70 \% \mathrm{SiO}_{2}, 26 \% \mathrm{CaO}\right.$ and $\left.4 \% \mathrm{P}_{2} \mathrm{O}_{5}\right)$ and $\mathrm{S} 80\left(80 \% \mathrm{SiO}_{2}, 16 \% \mathrm{CaO}\right.$ and $\left.4 \% \mathrm{P}_{2} \mathrm{O}_{5}\right)$ 22. All compositions formed an HCA layer in TRIS and in SBF within $12 \mathrm{~h}$. Ramila found that 
using CME produced a more uniform HCA layer on glasses compared to that formed on glasses made with calcium nitrate ${ }^{23}$. However all these glasses were stabilized at $700{ }^{\circ} \mathrm{C}$. CME was used in star gel synthesis where the final drying temperature was $90{ }^{\circ} \mathrm{C}^{24}$. Star gels are particular types of hybrids that have an organic core surrounded by flexible arms that terminate with alkoxysilane groups. The silica content of these materials is therefore low. Recently CME was used in the synthesis of electrospun silica/ polylactide (PLLA) hybrids, but again, the silica network was a small percentage of the material ${ }^{25}$. The potential for calcium incorporation into a silica network at low temperature was not assessed.

The aim of this work is to investigate the use of different calcium precursors for low temperature $\left(<130^{\circ} \mathrm{C}\right)$ sol-gel synthesis to assess their potential for the production of bioactive hybrids. The hypothesis was that CME would improve the incorporation of calcium into the solgel silica network at low temperature compared to the traditional method of using calcium salts. To achieve this, advanced probe techniques were employed to compare the effect of calcium precursor type on calcium incorporation in $70 \mathrm{~S} 30 \mathrm{C}$ and on their subsequent dissolution. To understand the mechanism of calcium incorporation, a range of sol-gel stabilization studies were used. The effect of HF was also investigated because, in porous scaffold production, HF is used to rapidly gel silica sols during foaming ${ }^{7}$. HF forms a complex with the silica, increasing the rate of bridging oxygen bond formation. It is therefore important to assess whether alternative calcium precursors modify the silica network formed by the action of $\mathrm{HF}^{26}$.

2. Materials and Methods

2.1 Sample preparation 
Glasses were made of the bioactive $70 \mathrm{~S} 30 \mathrm{C}\left(70 \mathrm{~mol} \% \mathrm{SiO}_{2}, 30 \mathrm{~mol} \% \mathrm{CaO}\right.$ ) composition. Three calcium precursors $\left(\mathrm{Ca}\left(\mathrm{NO}_{3}\right)_{2}, \mathrm{CaCl}_{2}\right.$ and $\left.\mathrm{CME}\right)$ were used to produce each of the glasses. Calcium acetate was also used in pilot studies. Sol-gel solutions were gelled with and without hydrofluoric acid (HF) and different heat treatments were applied to the gelled samples.

Commercial calcium methoxyethoxide (CME) was found to have inconsistent properties (i.e. dependent on supplier and batch), so CME was prepared following the method described by Pickup et al. ${ }^{27}: 1 \mathrm{~g}$ of calcium metal was reacted with $24 \mathrm{ml}$ of 2-methoxyethanol under an argon atmosphere at $80^{\circ} \mathrm{C}$ for $24 \mathrm{~h}$. The resultant solution was centrifuged at $6000 \mathrm{rpm}$ for 10 minutes to remove unreacted calcium metal. The concentration of CME in solution was confirmed gravimetrically by heating to $1050{ }^{\circ} \mathrm{C}$ for $12 \mathrm{~h}$ where the solvent evaporated and the CME converted to $\mathrm{CaO}$. This revealed the $\mathrm{CME}$ solution concentration to be $0.001 \mathrm{~mol} / \mathrm{ml}$.

Calcium nitrate containing samples were synthesized using an established sol-gel method ${ }^{28}$ (Figure 1, inorganic route). Deionised water and nitric acid $(2 \mathrm{~N})$ were mixed together and stirred for 5 minutes followed by addition of tetraethyl orthosilicate (TEOS) into the mixture. The R ratio (molar ratio of water:TEOS) was 12 . After $1 \mathrm{~h}$, calcium nitrate tetrahydrate was added to the sol and the sol was stirred for a further hour. Sols were poured into moulds and sealed. Gelation was allowed to occur at room temperature. To investigate the effect of a gelation catalyst, HF was added to selected samples at a ratio of $1.5 \mathrm{ml}$ of $\mathrm{HF}(0.5 \mathrm{w} / \mathrm{v})$ to $50 \mathrm{ml}$ of sol prior to pouring. Samples prepared without HF were left to complete gelation at room temperature for 3 days. For the preparation of the samples containing $\mathrm{CaCl}_{2}$ as the calcium 
precursor, the $\mathrm{Ca}\left(\mathrm{NO}_{3}\right)_{2}$ was replaced with $\mathrm{CaCl}_{2}$ and $2 \mathrm{~N}$ hydrochloric acid $(\mathrm{HCl})$ was used in place of $2 \mathrm{~N} \mathrm{HNO}_{3}$ to eliminate the nitrate by-products of $\mathrm{HNO}_{3}$.

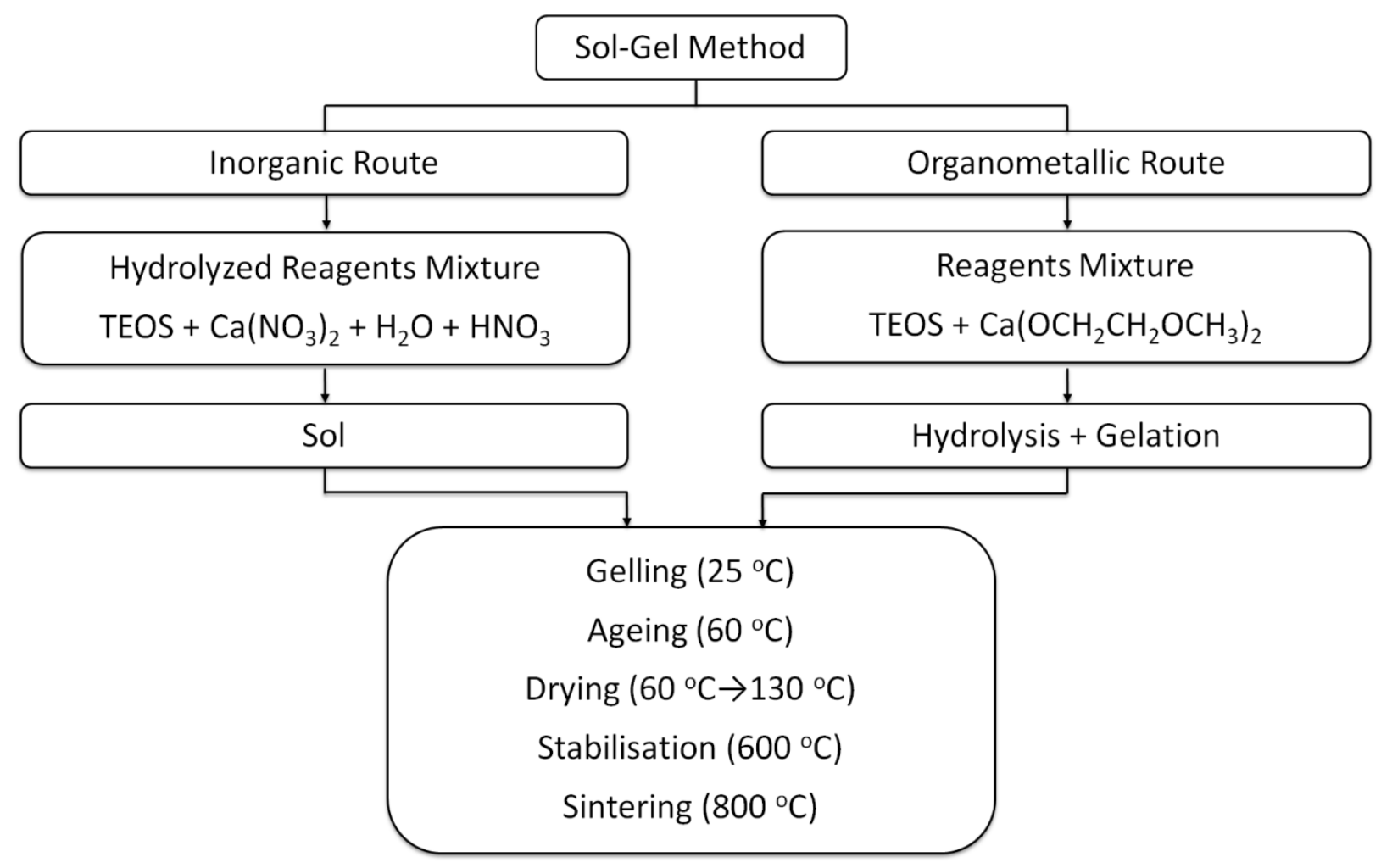

Figure 1. Flow chart of sol-gel methods used.

Synthesis with CME was performed by first mixing TEOS and CME under a nitrogen atmosphere (Figure 1, organic route). After $1 \mathrm{~h}$ of being stirred, the sol was hydrolysed by mixing with water inside a hermetically sealed container. $250 \mathrm{ml}$ of each sample was placed in a Teflon mould before heat treatment. The samples in the Teflon moulds were then left to age at room temperature for 3 days. Some of the $\mathrm{Ca}\left(\mathrm{NO}_{3}\right)_{2}, \mathrm{CaCl}_{2}$ and $\mathrm{CME}$ samples were taken through the full sol-gel heat treatment (dried at $60-130{ }^{\circ} \mathrm{C}$ and stabilized at $700{ }^{\circ} \mathrm{C}$ with some sintered at 800 ${ }^{\circ} \mathrm{C}$ after stabilization) to enable direct comparison with conventional sol-gel glasses prepared via the nitrate route. The amounts of chemicals used to synthesize the samples are listed in Table 1. 
All the resultant dry samples were ground to particle sizes of $38-90 \mu \mathrm{m}$. The glasses for the assessment of the calcium distribution were those dried at $130{ }^{\circ} \mathrm{C}$ (before stabilization); each sample was heated for one hour.

Table 1. Reagent quantities $(\mathrm{ml})$ used to synthesize $250 \mathrm{ml}$ batches of sol.

\begin{tabular}{cccccccc}
\hline Samples & $\begin{array}{c}\mathrm{H}_{2} \mathrm{O} \\
{[\mathrm{ml}]}\end{array}$ & $\begin{array}{c}2 \mathrm{~N} \mathrm{HNO}_{3} \\
{[\mathrm{ml}]}\end{array}$ & $\begin{array}{c}2 \mathrm{~N} \mathrm{HCl} \\
{[\mathrm{ml}]}\end{array}$ & $\begin{array}{c}\mathrm{TEOS} \\
{[\mathrm{ml}]}\end{array}$ & $\begin{array}{c}\mathrm{Ca}\left(\mathrm{NO}_{3}\right)_{2} \\
\bullet 4 \mathrm{H}_{2} \mathrm{O}[\mathrm{g}]\end{array}$ & $\begin{array}{c}\mathrm{CaCl}_{2} \\
{[\mathrm{~g}]}\end{array}$ & $\begin{array}{c}\mathrm{CME} \\
{[\mathrm{ml}]}\end{array}$ \\
\hline 70S30C-Ca($\left(\mathrm{NO}_{3}\right)_{2}$ & 135.90 & 22.68 & - & 141.12 & 63.72 & - & - \\
$70 \mathrm{~S} 30 \mathrm{C}-\mathrm{CaCl}_{2}$ & 135.90 & - & 22.68 & 141.12 & - & 39.67 & - \\
$70 \mathrm{S30C-CME}$ & 62.23 & - & - & 64.27 & - & - & 123.48
\end{tabular}

\subsection{Characterization}

\section{Composition}

The lithium metaborate fusion dissolution method was used in combination with inductive coupled plasma optical emission spectroscopy (ICP-OES) to determine the composition of the samples by measuring the ratio of $\mathrm{Si}$ and $\mathrm{Ca}^{29}$. The samples for this test were stabilized at 700 ${ }^{\circ} \mathrm{C}$ to remove moisture and $0.1 \mathrm{~g}$ of each sample was mixed with $0.5 \mathrm{~g}$ of anhydrous lithium metaborate in a clean dry platinum-gold crucible and fused at $1400{ }^{\circ} \mathrm{C}$ for 30 minutes. After cooling to room temperature, the crucible was immersed in a $250 \mathrm{ml}$ beaker filled with $80 \mathrm{ml}$ of 10 vol\% nitric acid and stirred overnight with a magnetic stirrer. The solution was then transferred to a $100 \mathrm{ml}$ polypropylene volumetric flask and filled up to the mark with $10 \mathrm{vol} \%$ nitric acid. The concentrations of $\mathrm{Si}, \mathrm{Ca}$, and $\mathrm{P}$ were then analyzed by ICP-OES (Thermo iCAP 
6000). The proportions of $\mathrm{SiO}_{2}, \mathrm{CaO}$, and $\mathrm{P}_{2} \mathrm{O}_{5}$ were obtained by comparing the molar ratio of $\mathrm{Si}, \mathrm{Ca}$, and $\mathrm{P}$.

\section{Surface area and pore size}

Meso-scale porosity was analyzed using nitrogen adsorption (Quantachrome AS6). The sol-gel frits were first degassed at room temperature over night to remove physically adsorbed gases, in particular water vapor. The surface area was calculated from the BET (Brunauer-Emmet-Teller) method ${ }^{30}$ and pore size distributions determined by applying the BJH (Barrett-Joyner-Halenda) ${ }^{31}$ method from the desorption branch of the isotherm ${ }^{32}$.

\section{Calcium distribution}

The X-ray diffraction (XRD) data was collected using a Bruker D8 Advance X-ray diffractometer with an incident wavelength of $1.54 \AA$. The heat treatment was undertaken by placing the samples inside a preheated oven for $1 \mathrm{~h}$ before slowly cooling to room temperature. $\mathrm{XRD}$ patterns were obtained at a range of temperatures to determine the temperature at which $\mathrm{Ca}$ enters the silica network.

Dissolution tests were carried out to evaluate the release speed of $\mathrm{Ca}, \mathrm{P}$, and $\mathrm{Si}$ as a function of stabilization temperature. These temperatures were selected according to the results obtained from XRD patterns. The samples sieved into 38-90 $\mu \mathrm{m}$ were immersed into deionized water and then placed in a shaker at $37{ }^{\circ} \mathrm{C}$, and an agitation rate of $120 \mathrm{rpm}$ was used. At each time point $(1,2,4,8,24,72,168,336$ and $672 \mathrm{~h}), 1 \mathrm{ml}$ extracts were taken and $1 \mathrm{ml}$ of deionized water was put back to keep the same water content. The ratio of sample to solution was $0.15 \mathrm{~g}$ to $100 \mathrm{ml}$. The concentration of $\mathrm{Ca}, \mathrm{Si}$, and $\mathrm{P}$ were also analyzed by ICP-OES. 


\section{$M A S-N M R$}

${ }^{29}$ Si magic angle spinning (MAS) NMR spectra were collected on a Varian InfinityPlus 300 MHz spectrometer operating at $59.62 \mathrm{MHz}$. A 30 s recycle delay and a $3 \mu$ s ( $30^{\circ}$ tip angle) pulse

were used which produced relaxed spectra. ${ }^{29} \mathrm{Si}$ spectra were referenced to tetramethylsilane (TMS) at $0 \mathrm{ppm}$.

\section{Bioactivity}

The effects of different calcium precursors and synthesis routes on the dissolution and bioactivity of glasses were investigated in a simulated body fluid (SBF) solution ${ }^{33}$ at a $\mathrm{pH}$ of 7.40 at $37{ }^{\circ} \mathrm{C}$. Aliquots of $75 \mathrm{mg}$ of each powder were immersed in $50 \mathrm{ml}$ of SBF and placed in an orbital shaker at $37^{\circ} \mathrm{C}$, for $2,8,24,72,168,336$ and $672 \mathrm{~h}$, using an agitation rate of 120 rpm, which are the optimal conditions determined from a previous study ${ }^{34}$. Three samples of each glass were run per test, with the mean values reported.

$\mathrm{Si}, \mathrm{Ca}$, and $\mathrm{P}$ concentrations in the SBF solutions obtained after filtration (1 $\mu \mathrm{m}$ paper) were analyzed by ICP-OES. The filtered powder was rinsed with acetone to terminate any ongoing reactions, dried and then evaluated by XRD and Fourier-transform Infrared spectroscopy (FTIR) analyses for the formation of an HCA layer. XRD was carried out with a PANalytical X'Pert Pro MPD series automated diffractometer, using a step scanning method with $\mathrm{Cu} \mathrm{K} \alpha$ radiation, at 40 $\mathrm{kV}$ and $40 \mathrm{~mA}$, with a $0.040^{\circ} 2 \theta$ step and a count rate of $50 \mathrm{~s}$ per step, for $2 \theta$ values of $5^{\circ}$ to $75^{\circ}$. FTIR spectra were obtained with a Bruker Vector 22 thermal gravimetric-infrared spectrometer (TGA-IR). Glass samples were finely ground with potassium bromide (KBr) in a 1 to 100 weight 
ratio and pressed into pellets. The sample was measured in transmission mode with a wavelength of $633 \mathrm{~nm}$ and in the range of 400 to $1600 \mathrm{~cm}^{-1}$.

\section{Results and Discussion}

\subsection{Composition}

In pilot studies, calcium acetate was tested as a potential calcium source. Previously it was used as a post-treatment solution rather than a calcium precursor ${ }^{35}$. Here, the calcium acetate caused rapid gelation without the need for $\mathrm{HF}$, but the calcium acetate precipitated during drying, leaving visible deposits on the samples. No further investigation of the use of calcium acetate was carried out.

The compositions, determined by the lithium metaborate fusion dissolution method, of the solgel glasses synthesized with the calcium nitrate, calcium chloride and CME, all stabilized at 700 ${ }^{\circ} \mathrm{C}$ are given in Table 2. All the compositions were within $1-2 \%$ of the nominal composition. This indicates that each of the calcium sources provided sufficient calcium, but it does not show whether the calcium was incorporated into the silica network.

Table 2. Compositional analysis of the sol-gel glass stabilised at $700{ }^{\circ} \mathrm{C}$ as determined by the lithium metaborate fusion dissolution and ICP.

\begin{tabular}{ccc}
\hline Samples & $\mathbf{S i O}_{2}$ & $\mathbf{C a O}$ \\
\hline 70S30C nominal & 70 & 30 \\
$70 \mathrm{~S} 30 \mathrm{C}-\mathrm{Ca}\left(\mathrm{NO}_{3}\right)_{2}$ & 69.9 & 30.1 \\
\hline
\end{tabular}




\begin{tabular}{lcc}
\hline 70S30C-CaCl & 71.3 & 28.7 \\
70S30C-CME & 70.7 & 29.3 \\
\hline
\end{tabular}

\subsection{Surface area and pore size}

Table 3 summarizes the mean specific surface area (SSA) and modal pore diameter ( $\left.\mathrm{d}_{\text {mode }}\right)$ data of the samples. The composition, final processing temperature and calcium precursor used all affected the pore size and SSA. Due to results of previous studies in the literature ${ }^{13,14}$, it was known that calcium is not incorporated into the silica network at when the gels are only dried at $60{ }^{\circ} \mathrm{C}$, therefore these samples were not synthesized. The $70 \mathrm{~S} 30 \mathrm{C}$ glasses made with calcium nitrate and stabilized at $700{ }^{\circ} \mathrm{C}$ (traditional sol-gel processing) had a SSA of $158 \mathrm{~m}^{2} \mathrm{~g}^{-1}$ and a $\mathrm{d}_{\text {mode }}$ of $17.5 \mathrm{~nm}$. The addition of HF not did affect these values. After sintering at $800{ }^{\circ} \mathrm{C}$, the SSA and $\mathrm{d}_{\text {mode }}$ for the HF free samples decreased due to further cross-linking of the $\mathrm{SiO}_{2}$ network under viscous flow of the glass during sintering. Sintering the samples made with HF did not change the pore size, although the SSA decreased from $156 \mathrm{~m}^{2} \mathrm{~g}^{-1}$ to $58 \mathrm{~m}^{2} \mathrm{~g}^{-1}$. When calcium chloride was used instead of calcium nitrate in glasses stabilized at $700{ }^{\circ} \mathrm{C}$, the SSA reduced to $44.8 \mathrm{~m}^{2} \mathrm{~g}^{-1}$ from $158 \mathrm{~m}^{2} \mathrm{~g}^{-1}$ but the $\mathrm{d}_{\text {mode }}$ was similar $(17 \mathrm{~nm})$. As the sintering temperature increased to $800{ }^{\circ} \mathrm{C}$, the pore size was no longer measureable by the $\mathrm{BJH}$ method, due to low adsorption of $\mathrm{N}_{2}$, i.e. there were no pores present or they were very small $(<2 \mathrm{~nm})$. This was due to densification by viscous flow. When HF was used, the SSA decreased to less than $20 \mathrm{~m}^{2} \mathrm{~g}^{-1}$ for sintering temperatures above $700{ }^{\circ} \mathrm{C}$.

An aim of using calcium chloride was that it could be used for low temperature synthesis, therefore samples with a final processing (drying) temperature of $60{ }^{\circ} \mathrm{C}$ were synthesized; which had a SSA of $13.3 \mathrm{~m}^{2} \mathrm{~g}^{-1}$ but no measurable pores. Monoliths could not be produced due to 
excessive cracking, due to the low porosity making drying difficult. Adding the HF increased the pore size, increasing the SSA to $75.6 \mathrm{~m}^{2} \mathrm{~g}^{-1}$ and $\mathrm{d}_{\text {mode }}$ to $17.5 \mathrm{~nm}$, reducing cracking. The effect of $\mathrm{HF}$ in the gelation process was also assessed from ${ }^{29} \mathrm{Si}$ MAS NMR spectroscopy (section 3.4.1). It therefore seems that the calcium chloride crystals fill the interstitial pores between silica nanoparticles that fuse together during silica network formation, and the calcium does not enter the silica network. XRD data (section 3.4.2) showed the crystals to be present.

Table 3. Surface area and modal pore diameter data collected from $\mathrm{N}_{2}$ sorption of materials synthesized with different calcium precursors, with and without HF and with different final processing temperatures.

\begin{tabular}{|c|c|c|c|c|c|c|}
\hline Samples & \multicolumn{2}{|c|}{$70 \mathrm{S30C} \mathrm{Ca}\left(\mathrm{NO}_{3}\right)_{2}$} & \multicolumn{2}{|c|}{$70 \mathrm{S30C} \mathrm{CaCl} 2$} & \multicolumn{2}{|c|}{ 70S30C CME } \\
\hline Dried at $60^{\circ} \mathrm{C}$ & no HF & HF & no HF & $\mathbf{H F}$ & no HF & HF \\
\hline Surface Area $\left(\mathrm{m}^{2} / \mathrm{g}\right)$ & $\mathrm{n} / \mathrm{a}$ & $\mathrm{n} / \mathrm{a}$ & 13.3 & 75.6 & 394.1 & 326.5 \\
\hline Modal Pore Diameter (nm) & $\mathrm{n} / \mathrm{a}$ & $\mathrm{n} / \mathrm{a}$ & - & 17.5 & 9.5 & 12.4 \\
\hline Stabilised at $700^{\circ} \mathrm{C}$ & no HF & HF & no HF & HF & no $\mathrm{HF}$ & HF \\
\hline Surface Area $\left(\mathrm{m}^{2} / \mathrm{g}\right)$ & 157.8 & 155.7 & 44.8 & 17.7 & 337.5 & 122.7 \\
\hline Modal Pore Diameter (nm) & 17.5 & 17.4 & 17.6 & 17.2 & 9.6 & 7.8 \\
\hline Sintered at $800^{\circ} \mathrm{C}$ & no HF & HF & no HF & $\mathbf{H F}$ & no HF & HF \\
\hline Surface Area $\left(\mathrm{m}^{2} / \mathrm{g}\right)$ & 62.0 & 58.0 & 31.1 & 15.3 & 31.8 & 47.5 \\
\hline Modal Pore Diameter (nm) & 12.4 & 17.2 & - & - & 3.4 & 5.6 \\
\hline
\end{tabular}

In contrast, using $\mathrm{CME}$ with a final drying temperature of $60^{\circ} \mathrm{C}$ produced $70 \mathrm{~S} 30 \mathrm{C}$ gels with a SSA of $394 \mathrm{~m}^{2} \mathrm{~g}^{-1}$ and a $\mathrm{d}_{\text {mode }}$ of $9.4 \mathrm{~nm}$. Adding HF caused a small increase in $\mathrm{d}_{\text {mode }}$ to $12.4 \mathrm{~nm}$. After thermal stabilization of the glass at $700^{\circ} \mathrm{C}$, the SSA and $\mathrm{d}_{\text {mode }}$ changed relatively little (338 
$\mathrm{m}^{2} \mathrm{~g}^{-1}$ and $9.6 \mathrm{~nm}$ respectively), indicating little change of structure as temperature increased and a glass more similar to the established 70S30C glasses made with calcium nitrate than to those made with calcium chloride. Nanopores form during the sol-gel process due to the disruption of the silica network, e.g. by calcium, and consequent evaporation of the liquid by-products of condensation (gelation). The presence of nanopores and the similar SSA and $\mathrm{d}_{\text {mode }}$ values between gels dried at $60{ }^{\circ} \mathrm{C}$ and glasses stabilized at $700{ }^{\circ} \mathrm{C}$ indicate that the calcium is integrated into the silica network at low temperature. Sintering the glasses made with CME had a dramatic effect, reducing SSA and $\mathrm{d}_{\text {mode }}$ to $47.5 \mathrm{~m}^{2} \mathrm{~g}^{-1}$ and $3.4 \mathrm{~nm}$ respectively. HF had little effect when the glasses were sintered at $800{ }^{\circ} \mathrm{C}$.

\subsection{XRD of glasses stabilized at $700^{\circ} \mathrm{C}$}

It is important that the new synthesis methods do not cause crystallization of the silica network as this would change the bioactivity of the materials. Previous work has shown 70S30C made with calcium nitrate to be amorphous after heating above $400{ }^{\circ} \mathrm{C}$ and below $850{ }^{\circ} \mathrm{C}{ }^{14}$. Below $400{ }^{\circ} \mathrm{C}$, XRD showed calcium nitrate to be present, indicating the calcium was not incorporated. Above $850{ }^{\circ} \mathrm{C}$, the glass crystallized to wollastonite ${ }^{14}$. Figure 2 shows XRD patterns for glasses stabilized at $700{ }^{\circ} \mathrm{C}$ with the different calcium precursors. Figure 2 shows that using calcium chloride caused phase separation (associated with peaks which could not be identified), indicating that calcium chloride is not a suitable calcium source. However, materials synthesized with CME were amorphous. 


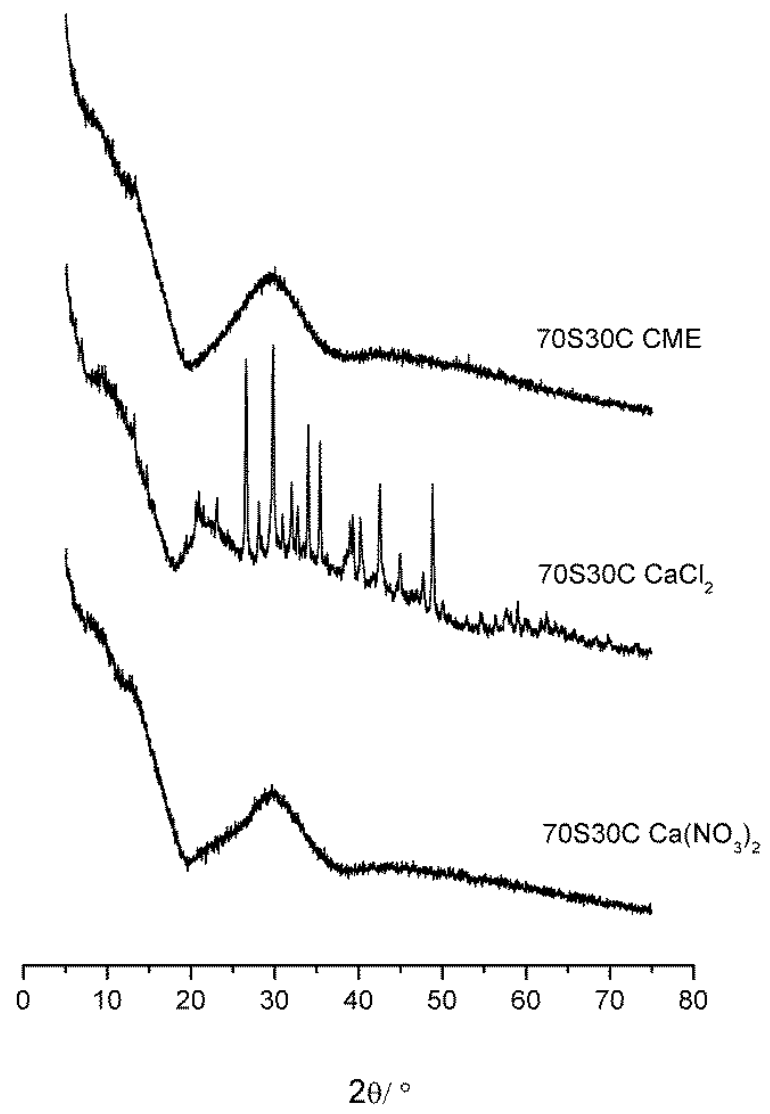

Figure 2. XRD patterns of as-synthesized bioactive glass samples after stabilization at $700{ }^{\circ} \mathrm{C}$, made with different calcium precursors: Calcium nitrate $\left(\mathrm{CaNO}_{3}\right)$; calcium chloride $\left(\mathrm{CaCl}_{2}\right)$ and calcium methoxyethoxide (CME).

Sintering at $800{ }^{\circ} \mathrm{C}$ did not cause further structural changes in any of the samples (data not shown). It is therefore worth investigating further the temperature at which the calcium enters the silica network during the process when CME is used, and whether there is potential for its use in the low temperature synthesis regimes required for the synthesis of hybrids. It is also important to determine whether glasses and gels formed with CME can form an apatite layer in SBF. 


\subsection{Effect of calcium precursor on calcium incorporation}

\subsubsection{NMR}

${ }^{29}$ Si MAS NMR spectroscopy provides data on the structural changes due to calcium incorporation and heat treatment by determining the distribution of silicon $\mathrm{Q}^{\mathrm{n}}$ species. $\mathrm{Q}^{\mathrm{n}}$ species are silicon atoms connected to other silicon atoms by $\mathrm{n}$ bridging oxygens (oxygen atoms covalently bonding to two silicon atoms forming Si-O-Si bonds). $\mathrm{Q}^{\mathrm{n}}$ corresponds to the structures of $\mathrm{Si}(\mathrm{OSi})_{n}(\mathrm{OR})_{4-n}$, where $\mathrm{OR}$ is a non-bridging oxygen $(\mathrm{NBO})$ which can either be a hydroxyl $(\mathrm{R}=\mathrm{H})$ or is a negatively charged oxygen (no $\mathrm{R}$ ) which then correspond to $\mathrm{Q}^{\mathrm{n}}(\mathrm{H})$ or $\mathrm{Q}^{\mathrm{n}}(\mathrm{Ca})$ species ${ }^{36-38}$. In the $70 \mathrm{~S} 30 \mathrm{C}$ sol-gel derived glasses, the presence of both $\mathrm{Q}^{\mathrm{n}}(\mathrm{H})$ and $\mathrm{Q}^{\mathrm{n}}(\mathrm{Ca})$ made the spectra deconvolution and specific peak assignment difficult. In this paper $\mathrm{Q}^{\mathrm{n}}$ species can have contributions from both $\mathrm{H}^{+}$(as an $\mathrm{OH}$ ) and $\mathrm{Ca}^{2+}$ as charge-balance for NBOs.

${ }^{29} \mathrm{Si}$ MAS NMR spectra of $70 \mathrm{~S} 30 \mathrm{C}$ samples synthesized from the three precursors and thermally treated at different temperatures are shown in Figure 3. To quantify the $\mathrm{Q}^{\mathrm{n}}$ distribution the ${ }^{29}$ Si MAS NMR spectra were deconvoluted by Gaussian fitting using DMFIT software ${ }^{39}$ and the results are shown in Table 4.

Our previous work showed that for $70 \mathrm{~S} 30 \mathrm{C}$ glasses synthesized from calcium nitrate, calcium was incorporated in the silicate network during the stabilization process (at $>400{ }^{\circ} \mathrm{C}$ ) ${ }^{14}$. Following drying at $130{ }^{\circ} \mathrm{C}$, there was a well polymerized silica network $\left(69 \% \mathrm{Q}^{4}, 27 \% \mathrm{Q}^{3}\right.$ and $\left.4 \% \mathrm{Q}^{2}\right)^{7}$. Stabilizing at $600{ }^{\circ} \mathrm{C}$ caused a decrease in $\mathrm{Q}^{4}$ to $36 \%{ }^{7}$, due to incorporation of calcium reducing the number of Si-O-Si bonds and increasing the number of non-bridging oxygen bonds. The percentage of $\mathrm{Q}^{3}$ was similar, but calcium incorporation was reflected as the amount of $\mathrm{Q}^{2}$ 
increased to $16 \%$, with $\mathrm{Q}^{1}$ and $\mathrm{Q}^{0}$ species appearing $\left(17 \%\right.$ and $8 \%$ respectively) ${ }^{14}$.

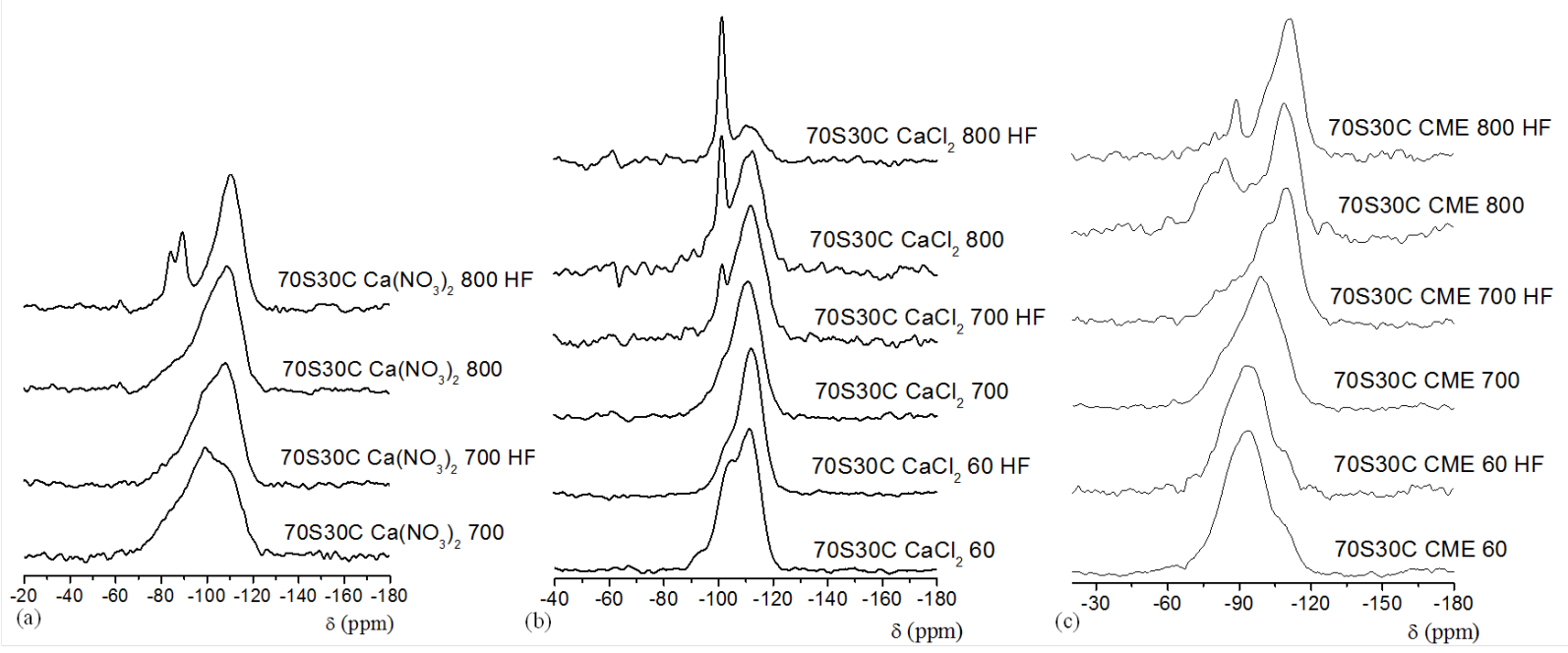

Figure 3. ${ }^{29} \mathrm{Si}$ solid state MAS-NMR spectra of $70 \mathrm{~S} 30 \mathrm{C}$ gels as a function of final processing temperature, following synthesis with (a) calcium nitrate $\left(\mathrm{CaNO}_{3}\right)$; (b) calcium chloride $\left(\mathrm{CaCl}_{2}\right)$ and (b) calcium methoxyethoxide (CME), all with and without the use of HF.

Table 4 shows that increasing the temperature to $700{ }^{\circ} \mathrm{C}$ caused a small amount of densification of the silica network with the percentage of $\mathrm{Q}^{4}$ increasing to $40 \%$. When the glass was sintered at $800{ }^{\circ} \mathrm{C}$ the amount of $\mathrm{Q}^{4}$ increased to $53 \%$ and $\mathrm{Q}^{2}$ species decreased to $14 \%$. $\mathrm{Q}^{3}$ species seem to remain the same as for the glass sintered at $700{ }^{\circ} \mathrm{C}$. This behavior can be explained by the fact that structural densification starts as the glass approaches glass transition temperature $\left(\mathrm{T}_{\mathrm{g}}\right) . \mathrm{T}_{\mathrm{g}}$ was previously measured as $717^{\circ} \mathrm{C}{ }^{8}$. Consequently, viscous flow occurs between 700 and $800{ }^{\circ} \mathrm{C}$ resulting in structural densification (i.e. increased connectivity) of the silicate network. 
Table $4{ }^{29}$ Si MAS NMR data, giving the spectral deconvolution into different $\mathrm{Q}^{\mathrm{n}}$ species.

\begin{tabular}{|c|c|c|c|c|c|c|c|c|c|c|c|c|c|c|c|}
\hline \multirow{2}{*}{$\begin{array}{l}\text { Sample } \\
\text { 70S30C }\end{array}$} & \multicolumn{3}{|l|}{$\mathrm{Q}^{0}$} & \multicolumn{3}{|l|}{$\mathrm{Q}^{1}$} & \multicolumn{3}{|l|}{$Q^{2}$} & \multicolumn{3}{|l|}{$Q^{3}$} & \multicolumn{3}{|l|}{$\mathrm{Q}^{4}$} \\
\hline & $\begin{array}{l}\delta \\
(\mathrm{ppm})\end{array}$ & $\begin{array}{l}\text { FWHM } \\
(\mathrm{ppm})\end{array}$ & $\begin{array}{l}\text { I } \\
(\%)\end{array}$ & $\begin{array}{l}\delta \\
(\mathrm{ppm})\end{array}$ & $\begin{array}{l}\text { FWHM } \\
(\mathrm{ppm})\end{array}$ & $\begin{array}{l}\text { I } \\
(\%)\end{array}$ & $\begin{array}{l}\delta \\
(\mathrm{ppm})\end{array}$ & $\begin{array}{l}\text { FWHM } \\
\text { (ppm) }\end{array}$ & $\begin{array}{l}\text { I } \\
(\%)\end{array}$ & $\begin{array}{l}\delta \\
(\mathrm{ppm})\end{array}$ & $\begin{array}{l}\text { FWHM } \\
(\mathrm{ppm})\end{array}$ & $\begin{array}{l}\mathrm{I} \\
(\%)\end{array}$ & $\begin{array}{l}\delta \\
(\mathrm{ppm})\end{array}$ & $\begin{array}{l}\text { FWHM } \\
(\mathrm{ppm})\end{array}$ & $\begin{array}{l}\text { I } \\
(\%)\end{array}$ \\
\hline $\mathrm{Ca}\left(\mathrm{NO}_{3}\right)_{2} 700$ & - & - & - & -79.5 & 11.4 & 10 & -90.0 & 12.4 & 24 & -98.8 & 10.1 & 26 & $\begin{array}{l}- \\
109.1\end{array}$ & 13.6 & 40 \\
\hline $\mathrm{Ca}\left(\mathrm{NO}_{3}\right)_{2} 700 \mathrm{HF}$ & - & - & - & -81.0 & 10.5 & 6 & -90.0 & 10.7 & 12 & -98.8 & 10.7 & 30 & $\begin{array}{l}- \\
108.9\end{array}$ & 12.1 & 52 \\
\hline $\mathrm{Ca}\left(\mathrm{NO}_{3}\right)_{2} 800$ & - & - & - & -81.1 & 11.1 & 7 & -90.7 & 11.3 & 14 & $\begin{array}{l}- \\
100.1\end{array}$ & 10.2 & 26 & $\begin{array}{l}- \\
109.8\end{array}$ & 11.8 & 53 \\
\hline $\mathrm{Ca}\left(\mathrm{NO}_{3}\right)_{2} 800 \mathrm{HF}$ & - & - & - & -78.9 & 6.8 & 3 & $\begin{array}{l}- \\
89.1^{b} \\
-84.0 \\
a\end{array}$ & $\begin{array}{l}4.4 \\
4.0\end{array}$ & $\begin{array}{l}12 \\
9\end{array}$ & $\begin{array}{l}- \\
100.3\end{array}$ & 13.2 & 17 & $\begin{array}{l}- \\
110.7\end{array}$ & 11.5 & 59 \\
\hline $\mathrm{CaCl}_{2} 60$ & - & - & - & - & - & - & -93.2 & 6.4 & 5 & - & 7.9 & 35 & $-\overline{111.5}$ & 9.2 & 60 \\
\hline $\mathrm{CaCl}_{2} 60 \mathrm{HF}$ & & & & & & & -95.0 & 4.9 & 1 & $\begin{array}{l}- \\
102.7\end{array}$ & 7.7 & 18 & $\begin{array}{l}- \\
112.2\end{array}$ & 9.6 & 81 \\
\hline $\mathrm{CaCl}_{2} 700$ & - & - & - & - & - & - & -94.3 & 7.4 & 5 & $\begin{array}{l}- \\
101.1\end{array}$ & 7.3 & 13 & $\begin{array}{l}- \\
110.9\end{array}$ & 11.4 & 82 \\
\hline $\mathrm{CaCl}_{2} 700 \mathrm{HF}$ & - & - & - & - & - & - & -97.0 & 5.8 & 2 & - & 2.5 & 5 & - & 11.4 & 77 \\
\hline
\end{tabular}




\begin{tabular}{|c|c|c|c|c|c|c|c|c|c|c|c|c|c|c|c|}
\hline & & & & & & & & & & \begin{tabular}{|l}
101.2 \\
$\mathrm{~d}$ \\
- \\
103.1
\end{tabular} & 11.5 & 16 & 112.1 & & \\
\hline $\mathrm{CaCl}_{2} 800$ & - & - & - & - & - & - & -95.1 & 9.3 & 8 & \begin{tabular}{|l}
- \\
101.4 \\
$d$ \\
- \\
100.7
\end{tabular} & $\begin{array}{l}2.6 \\
8.2\end{array}$ & $\begin{array}{l}11 \\
15\end{array}$ & $\begin{array}{l}- \\
112.3 \\
- \\
106.1\end{array}$ & $\begin{array}{l}10.2 \\
5.5\end{array}$ & $\begin{array}{l}60 \\
6\end{array}$ \\
\hline $\mathrm{CaCl}_{2} 800 \mathrm{HF}$ & - & - & - & - & - & - & - & - & - & $\begin{array}{l} \\
101.1 \\
- \\
\underset{d}{101.1}\end{array}$ & $\begin{array}{l}7.2 \\
2.6\end{array}$ & $\begin{array}{l}26 \\
34\end{array}$ & $\begin{array}{l}- \\
111.7\end{array}$ & 9.6 & 40 \\
\hline CME 60 & -76.6 & 11.3 & 10 & -85.3 & 9.1 & 23 & -92.4 & 9.1 & 29 & -98.6 & 9.1 & 22 & $\begin{array}{l}- \\
108.2\end{array}$ & 11.1 & 16 \\
\hline CME $60 \mathrm{HF}$ & -73.4 & 11.1 & 7 & -83.6 & 8.8 & 18 & -91.8 & 10.1 & 39 & -99.1 & 8.4 & 23 & $\begin{array}{l}- \\
108.3\end{array}$ & 9.4 & 13 \\
\hline CME 700 & -75.4 & 8.4 & 5 & -82.6 & 7.8 & 12 & -90.1 & 9.2 & 19 & -98.9 & 10.7 & 43 & $\begin{array}{l}- \\
108.0\end{array}$ & 9.9 & 21 \\
\hline CME $700 \mathrm{HF}$ & -76.5 & 6.6 & 4 & $\begin{array}{l}-83.6 \\
-79.9^{\mathrm{c}}\end{array}$ & $\begin{array}{l}5.8 \\
2.8\end{array}$ & $\begin{array}{l}6 \\
1\end{array}$ & $\begin{array}{l}-92.0 \\
-89.8 \\
\mathrm{~b} \\
-87.2\end{array}$ & $\begin{array}{l}8.1 \\
2.3 \\
3.0\end{array}$ & $\begin{array}{l}10 \\
1 \\
2\end{array}$ & -99.8 & 8.6 & 23 & $\begin{array}{l}- \\
110.0\end{array}$ & 11.3 & 53 \\
\hline
\end{tabular}




\begin{tabular}{|c|c|c|c|c|c|c|c|c|c|c|c|c|c|c|c|}
\hline & & & & & & & $\mathrm{b}$ & & & & & & & & \\
\hline CME 800 & -71.8 & 9.2 & 4 & -78.8 & 10.6 & 17 & $\begin{array}{l}-88.5 \\
-84.2 \\
\mathrm{a}\end{array}$ & $\begin{array}{l}10.2 \\
4.4\end{array}$ & $\begin{array}{l}11 \\
5\end{array}$ & -97.1 & 9.9 & 11 & $\begin{array}{l}- \\
109.5\end{array}$ & 12.3 & 52 \\
\hline CME $800 \mathrm{HF}$ & -68.7 & 5.2 & 2 & $\begin{array}{l}-79.8^{\mathrm{c}} \\
-75.6\end{array}$ & $\begin{array}{l}3.1 \\
4.2\end{array}$ & $\begin{array}{l}2 \\
2\end{array}$ & $\begin{array}{r}-92.0 \\
-88.6 \\
-83.8\end{array}$ & $\begin{array}{l}6.1 \\
3.8 \\
3.8\end{array}$ & $\begin{array}{l}4 \\
3 \\
2\end{array}$ & -99.8 & 8.6 & 23 & $\begin{array}{l}- \\
111.2\end{array}$ & 10.8 & 61 \\
\hline
\end{tabular}

FWHM, $\delta$ and I represent the linewidth full-width half-maximum, ${ }^{29} \mathrm{Si}$ chemical shift and relative intensity, respectively.

Errors associated with measurements are - FWHM $\pm 1 \mathrm{ppm}, \delta \pm 2 \mathrm{ppm}$ and Integral $\pm 2 \%$.

${ }^{\text {a }} \mathrm{Q}^{2}(\mathrm{Ca})$ in three-ring silicate ions in $\alpha-\mathrm{CaSiO}_{3}$ (pseudo-wollastonite)

${ }^{\mathrm{b}} \mathrm{Q}^{2}(\mathrm{Ca})$ in chain silicate ions in $\beta-\mathrm{CaSiO}_{3}$ (wollastonite)

${ }^{\mathrm{c}} \mathrm{Q}^{1}(\mathrm{Ca})$ in cuspidine, $\mathrm{Ca}_{4} \mathrm{Si}_{2} \mathrm{O}_{7} \mathrm{~F}_{2}$

${ }^{\mathrm{d}}$ unidentified crystalline phase, probably based on $\mathrm{Q}^{3}$ 
For glasses sintered at $800{ }^{\circ} \mathrm{C}$, Figure 3 shows that the presence of fluoride ions (due to use of $\mathrm{HF}$ as a catalyst) leads to the formation of crystalline calcium silicate crystalline phases as is evident in the spectrum of $70 \mathrm{~S} 30 \mathrm{C}-\mathrm{Ca}\left(\mathrm{NO}_{3}\right)_{2}-800 \mathrm{HF}$ sample (Figure 3a). This is because the $\mathrm{Q}^{2}(\mathrm{Ca})$ species in this sample exist in two environments. The chemical shifts at $-84.0 \mathrm{ppm}$ and $89.1 \mathrm{ppm}$ are assigned to $\mathrm{Q}^{2}(\mathrm{Ca})$ environments in $\alpha-\mathrm{Ca}_{3} \mathrm{Si}_{3} \mathrm{O}_{9}$ ring metasilicate (pseudowollastonite) and $\beta-\mathrm{Ca}_{3} \mathrm{Si}_{3} \mathrm{O}_{9}$ chain phases (wollastonite) which separate from the silicate network $^{40}$.

Figure $3 \mathrm{~b}$ and Table 4 show that when $\mathrm{CaCl}_{2}$ was used, calcium did not enter the silicate network at low processing temperature $\left(60^{\circ} \mathrm{C}\right)$. The silica network was well polymerised as suggested from the dominance of $Q^{4}(60 \%)$ and $Q^{3}$ species $(35 \%)$. The percentage of $Q^{4}$ species was higher than for glasses synthesized with calcium nitrate $(36 \%)$, indicating that calcium was not incorporated into the silica network, even at $700{ }^{\circ} \mathrm{C}$. When $\mathrm{HF}$ was used as the catalyst the concentration of $\mathrm{Q}^{4}$ species increased $(81 \%)$ and $\mathrm{Q}^{3}(\mathrm{H})$ decreased $(18 \%)$. This is due to the HF increasing the rate of condensation, causing formation of highly branched clusters and the gelation by linking of the clusters, producing a highly cross-linked silica network. Increasing the temperature to $700{ }^{\circ} \mathrm{C}$ in the $\mathrm{HF}$-free gel lead to further condensation between silanols which strengthened the silica network with an increase of the $Q^{4}$ concentration $(60 \%$ to $82 \%)$ and a correspondingly decrease (35\% to $13 \%$ ) of $Q$. $Q^{2}$ was just $5 \%$, indicating that little calcium was incorporated into the silicate network at $700{ }^{\circ} \mathrm{C}\left(\mathrm{Q}^{2}\right.$ was $24 \%$ when calcium nitrate was used). A further increase of the temperature to $800{ }^{\circ} \mathrm{C}$ leads to some phase separation with the peaks around -101 ppm. The peak position does not correspond to a known crystalline calcium silicates. Calcium does not seem to enter the silica network even at $800{ }^{\circ} \mathrm{C}$ as the $\mathrm{Q}^{\mathrm{n}}(\mathrm{Ca})$ species 
of lower connectivity are absent and the concentration of $\mathrm{Q}^{2}$ is low. Therefore calcium chloride is not a suitable calcium precursor for low or high temperature sol-gel synthesis.

For 70S30C samples synthesized by the alkoxide (CME and TEOS) route, the distributions of $\mathrm{Q}^{\mathrm{n}}$ structures was very different to the gels made with calcium salts (Figure $3 \mathrm{c}$ and Table 4). When the gels were dried at $60{ }^{\circ} \mathrm{C}$ they had $16 \% \mathrm{Q}^{4}, 22 \% \mathrm{Q}^{3}, 29 \% \mathrm{Q}^{2}, 23 \% \mathrm{Q}^{1}, 10 \% \mathrm{Q}^{0}$, indicating the calcium was well distributed throughout the silica network, reducing the number of bridging oxygen bonds and increasing the number of non-bridging oxygens. Condensation reactions between $\left(\mathrm{OC}_{2} \mathrm{H}_{5}\right)_{3} \mathrm{SiOH}$ and $\mathrm{HOCa}\left(\mathrm{OCH}_{2} \mathrm{CH}_{2} \mathrm{OCH}_{3}\right)$ obtained from the hydrolysis of TEOS and CME, take place in the early steps of the gel formation and form $\mathrm{SiO}^{-} \mathrm{Ca}^{2+-} \mathrm{OSi}$ nonbridging oxygens (NBOs). This explains the low concentration of $\mathrm{Q}^{4}$ species even at $60{ }^{\circ} \mathrm{C}$, because calcium is incorporated in the silicate matrix below this temperature. At this stage there seems to be a very small difference between samples synthesized with and without HF.

Increasing the temperature to $700{ }^{\circ} \mathrm{C}$, increased formation of new siloxane bridges and silanols, shown by the slight increase in $\mathrm{Q}^{4}$ and $\mathrm{Q}^{3}$ species. When structural densification occurred at $800{ }^{\circ} \mathrm{C}$, separation $\alpha-\mathrm{CaSiO}_{3}$ was observed.

When $\mathrm{F}^{-}$ions were present and the gels were stabilized at $700{ }^{\circ} \mathrm{C}$, the concentration of $\mathrm{Q}^{4}$ species increased substantially to $53 \%$ compared to $21 \%$ without HF, while the concentration of the silicate tetrahedra of lower connectivity $\left(\mathrm{Q}^{3}\right)$ decreased to $10 \%$ compared to $19 \%$ without HF. This could be due to the presence of the fluoride causing the structural densification to occur earlier with rapid formation of the silicate network. When fluoride was present, separation of 
silicate phases occurred at $700{ }^{\circ} \mathrm{C}$, which would account for the reduction in surface area when HF was used (Table 3), whereas a temperature of $800{ }^{\circ} \mathrm{C}$ was needed for this to occur without HF. It seems that when fluorine is involved, a chain configuration of $\mathrm{CaO} \cdot \mathrm{SiO}_{2}$ is preferred compared with the sample without fluorine where rings were found. The peak at $-80.0 \mathrm{ppm}$ can be assigned to silicon tetrahedra in the $\left.\mathrm{Q}^{1} \mathrm{Ca}\right)$ configuration in cuspidine $\left(\mathrm{Ca}_{4} \mathrm{Si}_{2} \mathrm{O}_{7} \mathrm{~F}_{2}\right)$, which can be formed at this temperature due to the affinity of fluorine for calcium ions and early formation of $\mathrm{CaF}_{2}$. This species has a reported chemical shift of $-79.9 \mathrm{ppm}^{41}$. As fluoride ions are at relatively low concentration the amount of this phase is small $(1-2 \%)$. This phase has been also detected in the literature in the melt-quench synthesized samples containing $\mathrm{CaF}_{2}{ }^{42}$. When $\mathrm{F}^{-}$ions are present in the system the structural densification seems to occur earlier. However, crystallization of calcium silicates does not take place until $800{ }^{\circ} \mathrm{C}$, when phase separation occurs giving rise to cuspidine and wollastonite.

The NMR data suggest that CME is an ideal calcium source for low temperature sol-gel synthesis. It was then important to determine how using CME affects calcium ion release in solution and whether glasses made with CME were bioactive in SBF.

\subsection{2 $\mathrm{XRD}$ as a function of calcium source and temperature}

Figure 4 shows the X-ray diffraction data for samples with different $\mathrm{Ca}$ precursors as a function of final thermal processing temperature, and dissolution data in deionised water for samples with specially chosen stabilization temperatures. The aim was to investigate how the final processing temperature affected calcium incorporation and consequently calcium release. Water was chosen because SBF contains calcium. 

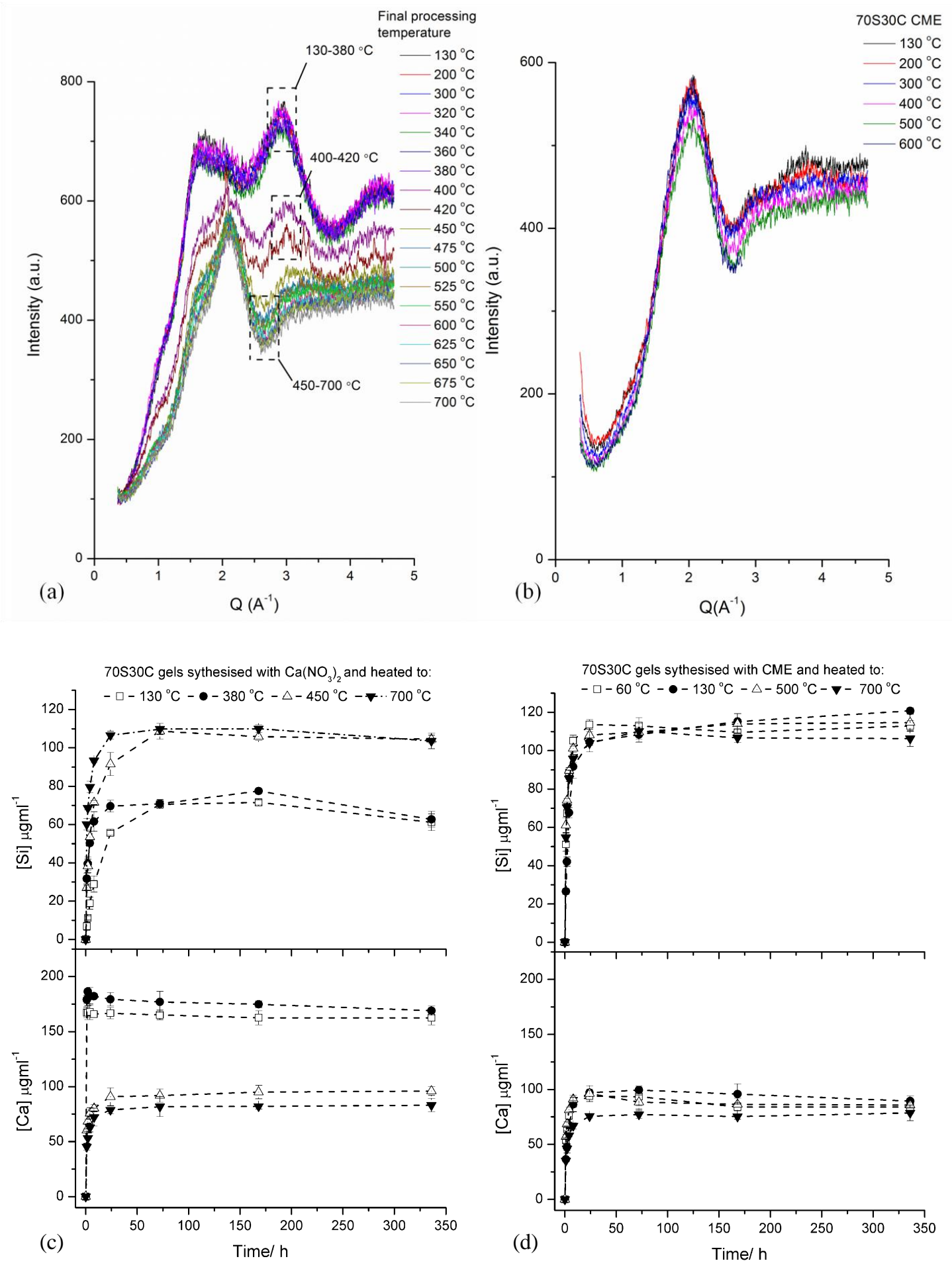

Figure 4. (a,b) X-ray diffraction patterns of 70S30C gels as a function of final processing temperatures using (a) calcium nitrate $\left(\mathrm{CaNO}_{3}\right)$; (b) calcium methoxyethoxide $(\mathrm{CME})$; (c, d) dissolution profiles of 70S30C gels following different final processing temperatures. 
Figure $4 \mathrm{a}$ shows the diffraction patterns for the $70 \mathrm{~S} 30 \mathrm{C}$ sample prepared using the $\mathrm{Ca}\left(\mathrm{NO}_{3}\right)_{2}$ - $4 \mathrm{H}_{2} \mathrm{O}$ precursor. The patterns can be divided into three categories as follows. The first subset, which show two clear principal peaks, correspond to the as-prepared 70S30C prior to heat treating through to samples heat treated up to $380^{\circ} \mathrm{C}$. The second subset corresponds to samples heat treated to $400{ }^{\circ} \mathrm{C}$ and $420{ }^{\circ} \mathrm{C}$ and reveals a transitional profile between the first and third subsets. The third subset, which has a single principal peak at $\mathrm{Q}=2.1 \AA^{-1}$, corresponds to samples heat treated above $450{ }^{\circ} \mathrm{C}$ and up to $700{ }^{\circ} \mathrm{C}$, which is below $\mathrm{T}_{\mathrm{g}}$ and the onset of crystallization. The diffraction pattern for this third subset is consistent with previously published diffraction data ${ }^{13,14}$, attributed to the nitrate decomposing and calcium entering the glass network. The patterns suggest that the calcium begins to enter and disrupt the silica network at $400{ }^{\circ} \mathrm{C}$ and is fully incorporated at $450{ }^{\circ} \mathrm{C}$. The temperatures selected for dissolution tests were therefore: $130{ }^{\circ} \mathrm{C}$ (usual drying temperature of gels prior to thermal stabilization), 380 ${ }^{\circ} \mathrm{C}$ (immediately before calcium incorporation), $450 \quad{ }^{\circ} \mathrm{C}$ (immediately after calcium incorporation) and $700{ }^{\circ} \mathrm{C}$ (stabilization temperature below $\mathrm{T}_{\mathrm{g}}$ ). Figure $4 \mathrm{c}$ and $4 \mathrm{~d}$ show the corresponding dissolution profiles in deionized water. Samples heated to $380{ }^{\circ} \mathrm{C}$ or less released calcium very rapidly $\left(179 \mu \mathrm{gml}^{-1}\right.$ within $2 \mathrm{~h}$ ). In contrast, samples heated above $450{ }^{\circ} \mathrm{C}$ only released $83 \mu \mathrm{gml}^{-1}$ (after heating to $450{ }^{\circ} \mathrm{C}$ ) of calcium ions and $96 \mu \mathrm{gml}^{-1}$ (after heating to 700 ${ }^{\circ} \mathrm{C}$ ) after 2 weeks immersion. These results show that, as anticipated, calcium did not incorporate into the network until $>380^{\circ} \mathrm{C}$. The silica release data supports this as samples heated to $\leq 380$ ${ }^{\circ} \mathrm{C}$ released less silica than those that incorporated the calcium in the network because without the calcium incorporated, the silica network has a higher connectivity which is more resistant to corrosion. The ${ }^{29} \mathrm{Si}$ MAS NMR data support this hypothesis (Figure 3 and Table 4). 
XRD (Figure 2) and ${ }^{29} \mathrm{Si} \mathrm{NMR}$ data for glasses synthesized with $\mathrm{CaCl}_{2}$ indicated that the calcium was never incorporated into the silica network (Figure 3 and Table 4) and the dissolution rate of calcium in the distilled water was approximately $200 \mu \mathrm{gml}^{-1}$ after $2 \mathrm{~h} \mathrm{immersion} \mathrm{for}$ samples dried at $130{ }^{\circ} \mathrm{C}$ and stabilized at $500{ }^{\circ} \mathrm{C}$ (data not shown).

Figure $4 \mathrm{~b}$ shows the diffraction patterns for the $70 \mathrm{~S} 30 \mathrm{C}$ sample prepared using the CME precursor. There was no change in the diffraction pattern following heat treatment with increasing temperatures. A single principal peak occurs at $Q=2.1 \AA^{-1}$ showing that calcium has already entered the glassy network at $130{ }^{\circ} \mathrm{C}{ }^{13}$. Dissolution tests were run at $60{ }^{\circ} \mathrm{C}$ (drying temperature of hybrids) and $130{ }^{\circ} \mathrm{C}$ (drying temperature prior to stabilization of glasses), 500 and $700{ }^{\circ} \mathrm{C}$ (the thermal stabilization temperature for glasses below $\mathrm{T}_{\mathrm{g}}$ ). Figure $4 \mathrm{~d}$ shows the dissolution profiles, which indicate that all the samples have very similar release rates of soluble silica and calcium, independent of the final processing temperature. Comparison with Figure 4c shows that the release rate of calcium was similar to that from the glass sample synthesized with calcium nitrate and heated to $700{ }^{\circ} \mathrm{C}$. This supports the hypothesis that calcium entered the silica network below $60{ }^{\circ} \mathrm{C}$. It is important to determine whether gels and glasses made with CME have the potential to be bioactive.

\subsection{Bioactivity testing}

Using CME allowed incorporation of calcium at low temperature. It was therefore important to determine whether the gel and glass made with $\mathrm{CME}$ can be considered bioactive. Figure 5 shows the XRD patterns of materials synthesized with CME as a function of drying or stabilization temperature and of each material following 4 weeks immersion in SBF. The patterns 
from samples synthesized without HF were amorphous at all final processing temperatures, even though the NMR data suggested some crystallization occurred after sintering at $800{ }^{\circ} \mathrm{C}$. Gels synthesized with $\mathrm{HF}$ and dried at $60^{\circ} \mathrm{C}$ contained small Bragg peaks representing $\mathrm{CaF}_{2}\left(28^{\circ}\right.$, $47^{\circ}, 56^{\circ}$, and $69^{\circ}$ ). This was attributed to the $\mathrm{HF}$ reacting with $\mathrm{Ca}$ from $\mathrm{CME}$ to form $\mathrm{CaF}_{2}$. This is not of significant concern as the amount of fluoride used in the process is low; indeed, fluoride-releasing bioactive glasses are themselves of interest in both orthopedic and dental applications as they can form fluorapatite ${ }^{42,43}$. When the gels were heated to $700{ }^{\circ} \mathrm{C}$, the $\mathrm{CaF}_{2}$ formed cuspidine $\left(\mathrm{Ca}_{4} \mathrm{Si}_{2} \mathrm{O}_{7} \mathrm{~F}_{2}\right)$. Samples not synthesized with $\mathrm{HF}$ remained XRD amorphous at all temperatures. All spectra that were collected from samples after 4 weeks immersion in SBF had peaks corresponding to HCA, indicating potential for bioactivity; however, the relative intensity of the HCA peaks decreased as the sintering temperature was increased from 700 to 800 ${ }^{\circ} \mathrm{C}$. This is likely to be due to densification of the silica network and the driving off of $-\mathrm{OH}$ groups (Table 4) which act as network modifiers to the silica network and nucleation sites for HCA. For potential hybrid synthesis, it is encouraging to see amorphous spectra after drying at $60{ }^{\circ} \mathrm{C}$ and even more encouraging to see HCA formation after immersion in SBF. 


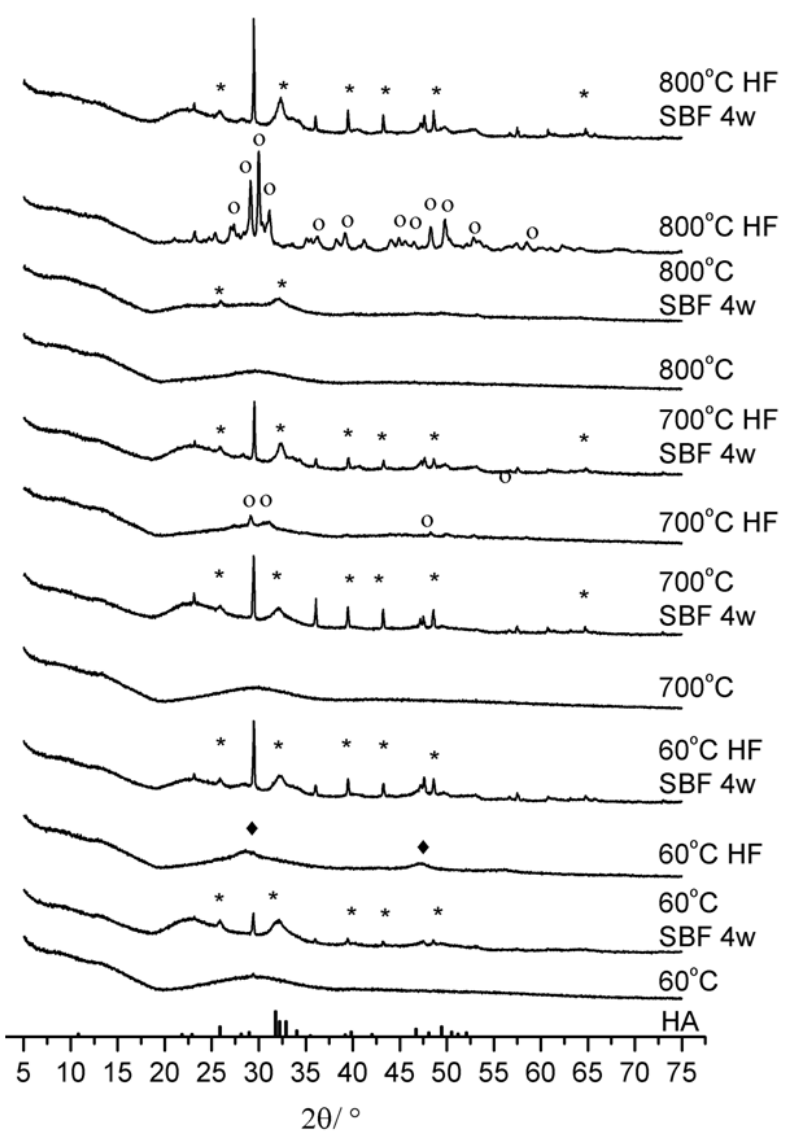

Figure 5. XRD patterns of 70S30C synthesized using calcium methoxyethoxide (CME) with different final processing temperatures and after reaction in SBF for 4 weeks, $(*)$ signifies the crystals of hydroxyapatite, $\left(^{\circ}\right)$ signifies the crystals of cuspidine, and $(\bullet)$ signifies crystals of calcium fluoride. The XRD pattern of hydroxyapatite powder is also included for reference.

HCA formation after 4 weeks in SBF is not enough to suggest bioactivity. If CME is to be used in bioactive hybrid synthesis, it is important that the gels made with CME and dried at 60 ${ }^{\circ} \mathrm{C}$ form an HCA layer in SBF in less than 1 week. Figure 6 shows FTIR spectra and XRD patterns of 70S30C gels synthesized with $\mathrm{CME}$ and dried at $60{ }^{\circ} \mathrm{C}$ (without $\mathrm{HF}$ ) after different immersion times in SBF. The FTIR spectrum of the unreacted gel (Figure 6a), before immersion, contains vibration bands (875 and $1400 \mathrm{~cm}^{-1}$ which are $\mathrm{C}-\mathrm{O}$ stretching and bending modes 
respectively) corresponding to the formation of surface carbonates. The splitting of $\sim 100 \mathrm{~cm}^{-1}$ of $v_{3}$ vibration indicates the formation of monodentate carbonates. Figure $6 \mathrm{a}$ shows that within $2 \mathrm{~h}$ of immersion, a broad absorbance band $\left(550-600 \mathrm{~cm}^{-1}\right)$ often attributed to amorphous phosphate species was present ${ }^{44}$. After immersion for $24 \mathrm{~h}$ the P-O bending bands that are associated with orthophosphate $\left(571\right.$ and $602 \mathrm{~cm}^{-1}$ ) evolved. The vibration corresponding to $\delta_{\text {Si-O-Si }}$ at $800 \mathrm{~cm}^{-1}$ increased in intensity after the sample was immersed in SBF, suggesting the formation of silicarich layer. After 24 and $72 \mathrm{~h}$ of immersion, the reappearance of vibration bands at $1410 \mathrm{~cm}^{-1}$ and $870 \mathrm{~cm}^{-1}$ indicate a B type carbonate substitution in $\mathrm{HA}$, while the vibration at $1460 \mathrm{~cm}^{-1}$ is for an A substitution. Therefore an $\mathrm{AB}$ carbonate substituted apatite is formed, indicative of HCA. XRD patterns (Figure 6b) show crystalline peaks that can be assigned to HCA ( $2 \theta$ value of approximately $31^{\circ}$ ) are present after $24 \mathrm{~h}$ immersion. A small peak was present at $8 \mathrm{~h}$. These results indicate that $\mathrm{CME}$ can produce bioactive gels. Calcite was also detected in the XRD patterns after $24 \mathrm{~h}$ immersion. 

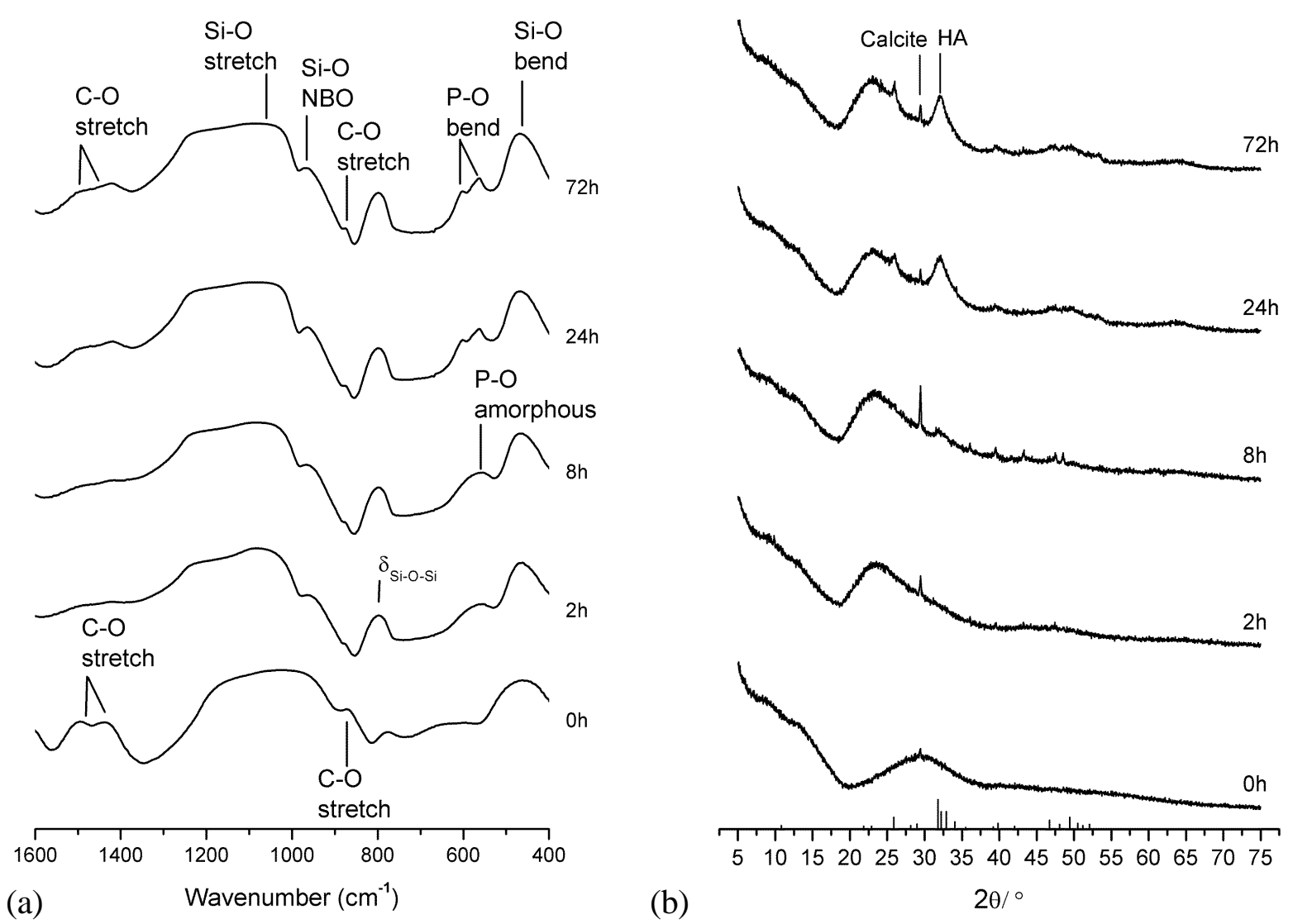

Figure 6. 70S30C gel synthesized with $\mathrm{CME}$ and dried at $60{ }^{\circ} \mathrm{C}$ after immersion in simulated body fluid as a function of time: (a) FTIR (b) XRD, including the XRD pattern of HA.

Figure 7a shows the release profiles in SBF of soluble silicon, calcium and phosphorus species from gels made with $\mathrm{CME}$ and $\mathrm{CaCl}_{2}$ precursors and dried at $60^{\circ} \mathrm{C}$. Over the first week of immersion in SBF, the calcium content of the SBF was approximately $50 \mu \mathrm{gml}^{-1}$ higher $(257.3$ $\left.\mu \mathrm{gml}^{-1}\right)$ for samples synthesized with $\mathrm{CME}$ compared to those synthesized with $\mathrm{CaCl}_{2}(206.8$ $\mu \mathrm{gml}^{-1}$ ). This is either due to the samples made with CME releasing more calcium ions, or due to the gels made with $\mathrm{CaCl}_{2}$ nucleating more calcium species, e.g. HA. The phosphorus content of the SBF decreased rapidly after the gels were immersed, from $33 \mu \mathrm{gml}^{-1}$ to around $10 \mu \mathrm{gml}^{-1}$, and all the phosphorus was removed from the SBF by $72 \mathrm{~h}$, indicating possible calcium 
phosphate nucleation, which is in line with the XRD and FTIR data (Figure 6). Dissolution profiles of samples gelled with HF were very similar (data not shown).

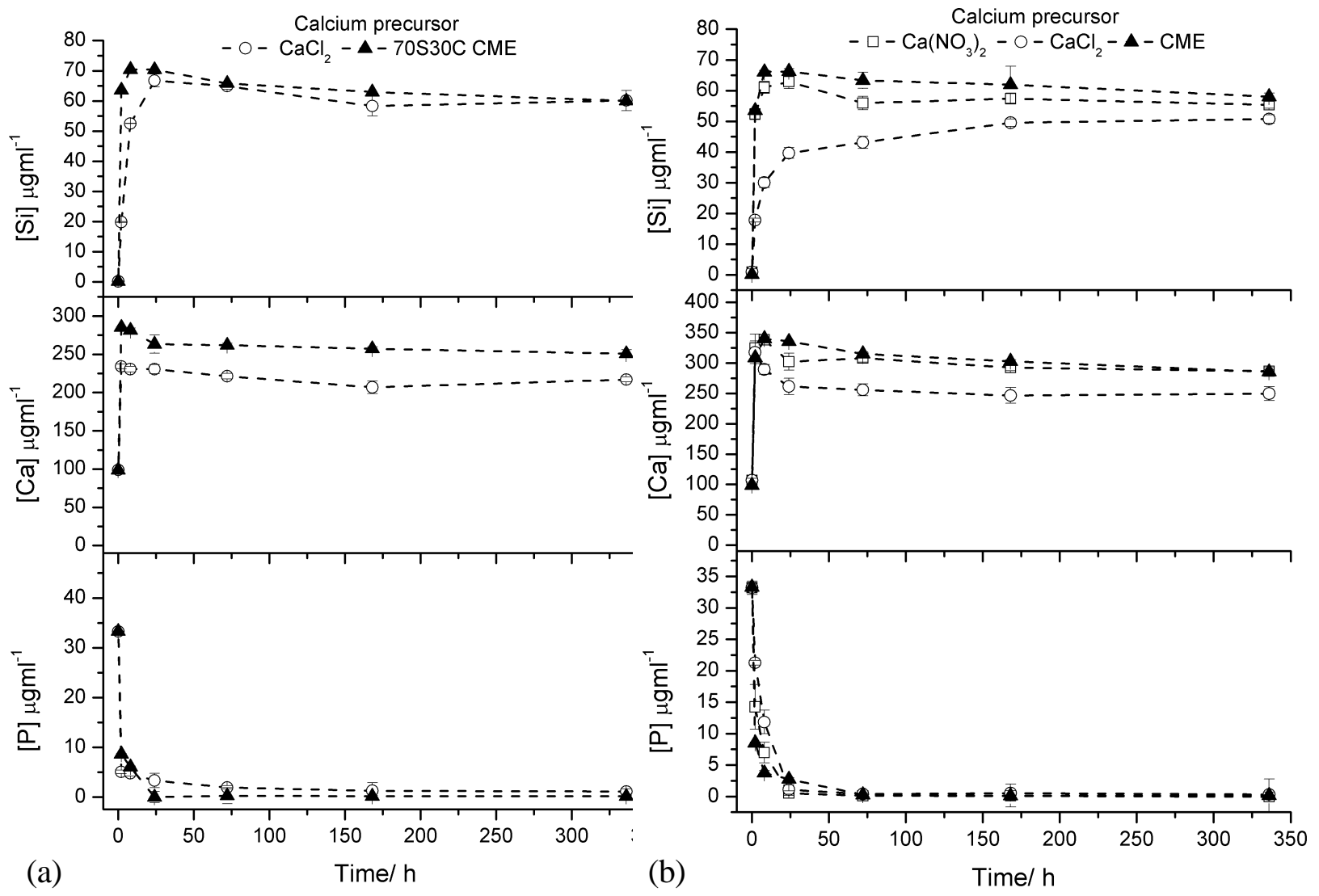

Figure 7. ICP data of simulated body fluid after immersion of 70S30C gels synthesized with different calcium precursors and using different final processing temperatures of (a) $60{ }^{\circ} \mathrm{C}$ and (b) $700{ }^{\circ} \mathrm{C}$.

Figure $7 \mathrm{~b}$ shows the dissolution profiles in SBF following immersion of the glasses stabilized at $700{ }^{\circ} \mathrm{C}$. The silica release rate was slightly lower than for the gels. The glasses synthesized with calcium chloride had the lowest release rate of soluble silica (around $30 \mu \mathrm{gml}^{-1}$ after $8 \mathrm{~h}$ ). The reason for this is that the glasses synthesized with calcium chloride had SSA values up to an 
order of magnitude smaller than those made with calcium nitrate or CME and due to the higher percentage of $\mathrm{Q}^{4}$ units (approximately double that of the other glasses). Glasses made with either calcium nitrate or CME had similar dissolution rates, with CME glasses slightly higher at approximately $70 \mu \mathrm{gml}^{-1}$ after $8 \mathrm{~h}$. The reason for the higher dissolution of CME glasses is attributed to their higher SSA (Table 3). The phosphorus concentration in the SBF decreased rapidly immediately after immersion for all samples, reaching zero by $24 \mathrm{~h}$, indicating possible HCA formation. For the glasses that were gelled with HF, the release profiles showed similar trends (data not shown) except that the silica and calcium ion release rates were slightly lower, e.g. 70S30C synthesized with CME, silica release was $52.1 \mu \mathrm{gml}^{-1}$ after $8 \mathrm{~h}$ for glasses gelled with HF compared to $66.1 \mu \mathrm{gml}^{-1}$ for glasses gelled without HF. This is due to the significant decrease of surface area from $\sim 340 \mathrm{~m}^{2} \mathrm{~g}^{-1}$ (without HF) to $120 \mathrm{~m}^{2} \mathrm{~g}^{-1}$ (with HF). When the glasses were sintered to $800{ }^{\circ} \mathrm{C}$, the dissolution of the glasses decreased, e.g. $70 \mathrm{~S} 30 \mathrm{C}$ synthesized with CME released $31.5 \mathrm{\mu gml}^{-1}$ of soluble silica after $8 \mathrm{~h}$ immersion when sintered at $800{ }^{\circ} \mathrm{C}$ compared to $66.1 \mu \mathrm{gml}^{-1}$ when stabilized at $700^{\circ} \mathrm{C}$. This is again likely to be due to densification

of the silica network (Table 4) and associated SSA decrease from $340 \mathrm{~m}^{2} \mathrm{~g}^{-1}$ to $32 \mathrm{~m}^{2} \mathrm{~g}^{-1}$ during sintering at $800{ }^{\circ} \mathrm{C}$. As a result of this, the phosphate precipitation within the SBF was slower, indicating slower HCA formation (which seems to form at around 3 days of immersion).

\section{Summary}

CME seems to be an excellent alternative to calcium salts for incorporation of calcium into the silica network at processing temperatures below $60{ }^{\circ} \mathrm{C}$. The hypothesis for the mechanism of incorporation of the calcium is that the CME hydrolyses when it is added to the hydrolyzed TEOS sol and incorporates calcium into the wet gel. As gelation and drying proceed, the silica 
network continues to cross-link but maintains the calcium in the network. In contrast, when calcium salts are used they remain in solution until drying, only being incorporated when they are broken down thermally at high temperature, or in the case of calcium chloride, not at all. The use of calcium nitrate in the sol-gel process has recently been shown to cause inhomogeneity in the calcium distribution ${ }^{12,15}$; $\mathrm{CME}$ is therefore a promising alternative for the production of more homogeneous glasses and in the synthesis of sol-gel hybrid materials containing organic polymers.

\section{Conclusions}

The results confirm the earlier observation that when sol-gel glasses are synthesized with calcium nitrate, the calcium only enters the network above $\sim 400{ }^{\circ} \mathrm{C}$. When calcium chloride is used as an alternative, calcium is not incorporated at any temperature. Calcium salts are therefore not useful calcium sources for the low temperature $\left(\sim 60{ }^{\circ} \mathrm{C}\right)$ synthesis regimes required for glasspolymer hybrids. Calcium was found to enter the glassy network during the drying process for 70S30C prepared using CME. The use of $\mathrm{HF}$ as a gelation catalyst did not affect calcium incorporation, although some calcium fluoride was formed. Heating the dried gels synthesized with CME to the temperatures used for stabilizing sol-gel glasses did not change the calcium dissolution or structure of the silica network. CME is therefore a suitable calcium precursor for synthesizing bioactive sol-gel glasses, low temperature gels and potentially hybrids.

\section{Acknowledgements}

JRJ acknowledges the EPSRC Challenging Engineering Scheme (EP/I02086). He was a Royal Academy of Engineering/EPSRC Research Fellow and also acknowledges support from the 
Royal Society and the Philip Leverhulme Prize. The authors also acknowledge support from the EPSRC (EP/E057098/1 and EP/E050611/1). The NMR equipment used in this research received funding from EPSRC, BBSRC, the University of Warwick and Birmingham Science City Projects supported by Advantage West Midlands and the European Regional Development Fund.

\section{References}

(1) Hench, L. L.; Polak, J. M., Third-generation biomedical materials. Science 2002, 295 (5557), 1014-1017.

(2) Valliant, E. M.; Jones, J. R., Softening bioactive glass for bone regeneration: sol-gel hybrid materials. Soft Matter 2011, 7 (11), 5083-5095.

(3) Jones, J. R., Review of bioactive glass: From Hench to hybrids. Acta Biomater 2012, http://dx.doi.org/10.1016/j.actbio.2012.08.023.

(4) Hench, L. L.; Splinter, R. J.; Allen, W. C.; Greenlee, T. K., Bonding mechanisms at the interface of ceramic prosthetic materials. J. Biomed. Mater. Res. Symp. 1971, 5 (6), 117-141.

(5) Li, R.; Clark, A. E.; Hench, L. L., An investigation of bioactive glass powders by sol-gel processing. J. Appl. Biomater. 1991, 2 (4), 231-239.

(6) Sepulveda, P.; Jones, J. R.; Hench, L. L., Characterization of melt-derived 45S5 and solgel-derived 58S bioactive glasses. J. Biomed. Mater. Res. 2001, 58 (6), 734-740.

(7) Sepulveda, P.; Jones, J. R.; Hench, L. L., Bioactive sol-gel foams for tissue repair. J. Biomed. Mater. Res. 2002, 59 (2), 340-348. 
(8) Jones, J. R.; Ehrenfried, L. M.; Hench, L. L., Optimising bioactive glass scaffolds for bone tissue engineering. Biomaterials 2006, 27, 964-973.

(8) Lin, S.; Ionescu, C.; Baker, S.; Smith, M. E.; Jones, J. R., Characterisation of the inhomogeneity of sol-gel-derived $\mathrm{SiO}_{2}-\mathrm{CaO}$ bioactive glass and a strategy for its improvement. J. Sol-Gel Sci. Technol. 2010, 53, 255-262.

(9) Hench, L. L.; Vasconcelos, W., Gel-silica science. Ann. Rev. Mater. Sci. 1990, 20, 269298.

(10) Hench, L. L.; West, J. K., The sol-gel process. Chem. Rev. 1990, 90 (1), 33-72.

(11) Brinker, J.; Scherer, G. W., Sol-gel science : the physics and chemistry of sol-gel processing. Academic Press: Boston, 1990.

(12) Seebach, C.; Schultheiss, J.; Wilhelm, K.; Frank, J.; Henrich, D., Comparison of six bone-graft substitutes regarding to cell seeding efficiency, metabolism and growth behaviour of human mesenchymal stem cells (MSC) in vitro. Injury 2010, 41 (7), 731-738.

(13) Skipper, L. J.; Sowrey, F. E.; Pickup, D. M.; Drake, K. O.; Smith, M. E.; Saravanapavan, P.; Hench, L. L.; Newport, R. J., The structure of a bioactive calcia-silica sol-gel glass. J. Mater. Chem. 2005, 15 (24), 2369-2374.

(14) Lin, S.; Ionescu, C.; Pike, K. J.; Smith, M. E.; Jones, J. R., Nanostructure evolution and calcium distribution in sol-gel derived bioactive glass. J. Mater. Chem. 2009, 19 (9), 1276-1282.

(15) Yue, S.; Lee, P. D.; Poologasundarampillai, G.; Yao, Z.; Rockett, P.; Devlin, A. H.; Mitchell, C. A.; Konerding, M. A.; Jones, J. R., Synchrotron X-ray microtomography for assessment of bone tissue scaffolds. J Mater. Sci. Mater. Med. 2010, 21 (3), 847-53. 
(16) Bonhomme, C.; Gervais, C.; Folliet, N.; Pourpoint, F.; Diogo, C. C.; Lao, J.; Jallot, E.; Lacroix, J.; Nedelec, J. M.; Iuga, D.; Hanna, J. V.; Smith, M. E.; Xiang, Y.; Du, J. C.; Laurencin, D., Sr-87 solid-state NMR as a structurally sensitive tool for the investigation of materials: Antiosteoporotic pharmaceuticals and bioactive glasses. J. Am. Chem. Soc. 2012, 134 (30), 12611-12628.

(17) Novak, B. M., Hybrid nanocomposite materials - between inorganic glasses and organic polymers. Adv. Mater. 1993, 5 (6), 422-433.

(18) Mahony, O.; Tsigkou, O.; Ionescu, C.; Minelli, C.; Ling, L.; Hanly, R.; Smith, M. E.; Stevens, M. M.; Jones, J. R., Silica-Gelatin Hybrids with Tailorable Degradation and Mechanical Properties for Tissue Regeneration. Adv. Funct. Mater. 2010, 20 (22), 3835-3845.

(13) Poologasundarampillai, G.; Ionescu, C.; Tsigkou, O.; Murugesan, M.; Hill, R. G.; Stevens, M. M.; Hanna, J. V.; Smith, M. E.; Jones, J. R., Synthesis of bioactive class II poly(gglutamic acid)/silica hybrids for bone regeneration. J. Mater. Chem. 2010. 20 (40), 8952-8961.

(14) Pereira, M. M.; Clark, A. E.; Hench, L. L., Calcium-Phosphate Formation on Sol-GelDerived Bioactive Glasses in-Vitro. J. Biomed. Mater. Res. 1994, 28 (6), 693-698.

(15) Ramila, A.; Balas, F.; Vallet-Regi, M., Synthesis routes for bioactive sol-gel glasses: Alkoxides versus nitrates. Chem. Mater. 2002, 14 (2), 542-548.

(16) Manzano, M.; Arcos, D.; Delgado, M. R.; Ruiz, E.; Gil, F. J.; Vallet-Regi, M., Bioactive star gels. Chem. Mater. 2006, 18 (24), 5696-5703.

(17) Poologasundarampillai, G.; Yu, B. B.; Jones, J. R.; Kasuga, T., Electrospun silica/PLLA hybrid materials for skeletal regeneration. Soft Matter 2011, 7 (21), 10241-10251. 
(18) Pickup, D. M.; Valappil, S. P.; Moss, R. M.; Twyman, H. L.; Guerry, P.; Smith, M. E.; Wilson, M.; Knowles, J. C.; Newport, R. J., Preparation, structural characterisation and antibacterial properties of Ga-doped sol-gel phosphate-based glass. J. Mater. Sci. 2009, 44 (7), 1858-1867.

(19) Mahony, O.; Tsigkou, O.; Ionescu, C.; Minelli, C.; Hanly, R.; Ling, L.; Smith, M. E.; Stevens, M. M.; Jones, J. R., Silica-gelatin hybrids with tailorable degradation and mechanical properties for tissue regeneration. Adv. Funct. Mater. 2010, 20, 3835-3845.

(20) Rhee, S. H.; Lee, Y. K.; Lim, B. S., Evaluation of a novel poly(epsilon-caprolactone)organosiloxane hybrid material for the potential application as a bioactive and degradable bone substitute. Biomacromolecules 2004, 5 (4), 1575-1579.

(21) Miyazaki, T.; Ohtsuki, C.; Tanihara, M., Synthesis of bioactive organic-inorganic nanohybrid for bone repair through sol-gel processing. J. Nanosci. Nanotechnol. 2003, 3 (6), $511-515$

(22) Pereira, M. M.; Clark, A. E.; Hench, L. L., Calcium-phosphate formation on sol-gelderived bioactive blasses in vitro. J. Biomed. Mater. Res. 1994, 28 (6), 693-698.

(23) Ramila, A.; Balas, F.; Vallet-Regi, M., Synthesis routes for bioactive sol-gel glasses: Alkoxides versus nitrates. Chem. Mater. 2002, 14 (2), 542-548.

(24) Manzano, M.; Arcos, D.; Delgado, M. R.; Ruiz, E.; Gil, F. J.; Vallet-Regi, M., Bioactive star gels. Chem. Mater. 2006, 18 (24), 5696-5703.

(25) Poologasundarampillai, G.; Yu, B. B.; Jones, J. R.; Kasuga, T., Electrospun silica/PLLA hybrid materials for skeletal regeneration. Soft Matter 2011, 7 (21), 10241-10251. 
(26) Powers, K. W.; Hench, L. L., The pentacoordinate species in fluoride catalysis of silica gels. In Sol-Gel Synthesis and Processing, Komarneni, S.; Sakka, S.; Phule, P. P.; Laine, R. M., Eds. Amer Ceramic Soc: Westerville, 1998; Vol. 95, pp 197-206.

(27) Pickup, D. M.; Valappil, S. P.; Moss, R. M.; Twyman, H. L.; Guerry, P.; Smith, M. E.; Wilson, M.; Knowles, J. C.; Newport, R. J., Preparation, structural characterisation and antibacterial properties of Ga-doped sol-gel phosphate-based glass. J. Mater. Sci. 2009, 44 (7), $1858-1867$.

(28) Saravanapavan, P.; Hench, L. L., Mesoporous calcium silicate glasses. I. Synthesis. $J$. Non-Cryst. Solids 2003, 318 (1-2), 1-13.

(29) Casoli, A.; Mirti, P., The analysis of archaeological glass by inductively coupled plasma optical-emission spectroscopy. Fresenius J. Anal. Chem. 1992, 344 (3), 104-108.

(30) Brunaur, S.; Deming, L. S.; Deming, W. S.; Teller, E., On a theory of the vander waals adsorption of gases. J. Am. Chem. Soc. 1940, 62, 1723-1732.

(31) Barrett, E. P.; Joyner, L. G.; Halenda, P. P., The determination of pore volume and area distributions in porous substances. I. computations from nitrogen isotherms. J. Am. Chem. Soc. 1951, $73(1), 373-380$.

(32) Sing, K. S. W.; Everett, D. H.; Haul, R. A. W.; Moscou, L.; Pierotti, R. A.; Rouquerol, J.; Siemieniewska, T., Reporting Physisorption Data for Gas Solid Systems with Special Reference to the Determination of Surface-Area and Porosity (Recommendations 1984). Pure Applied Chem. 1985, 57 (4), 603-619. 
(33) Kokubo, T.; Takadama, H., How useful is SBF in predicting in vivo bone bioactivity? Biomaterials 2006, 27 (15), 2907-2915.

(34) Jones, J. R.; Sepulveda, P.; Hench, L. L., Dose-dependent behavior of bioactive glass dissolution. J. Biomed. Mater. Res. 2001, 58 (6), 720-726.

(35) de Oliveira, A. A. R.; Ciminelli, V.; Dantas, M. S. S.; Mansur, H. S.; Pereira, M. M., Acid character control of bioactive glass/polyvinyl alcohol hybrid foams produced by sol-gel. J. SolGel Sci. Technol. 2008, 47 (3), 335-346.

(36) MacKenzie, K. J. D.; Smith, M. E., Multinuclear solid state NMR of inorganic materials. Pergamon Press: Oxford, 2002.

(37) Chuang, I. S.; Kinney, D. R.; Maciel, G. E., Interior hydroxyls of the silica-gel system as studied by Si-29 CP-MAS NMR spectroscopy. J. Am. Chem. Soc. 1993, 115 (19), 8695-8705.

(38) Liu, C. H. C.; Maciel, G. E., The fumed silica surface: A study by NMR. J. Am. Chem. Soc. 1996, $118(21), 5103-5119$.

(39) Massiot, D.; Fayon, F.; Capron, M.; King, I.; Le Calve, S.; Alonso, B.; Durand, J. O.; Bujoli, B.; Gan, Z. H.; Hoatson, G., Modelling one- and two-dimensional solid-state NMR spectra. Magn. Reson. Chem. 2002, 40 (1), 70-76.

(40) Engelhardt, G.; Nofz, M.; Forkel, K.; Wihsmann, F. G.; Magi, M.; Samoson, A.; Lippmaa, E., Structural studies of calcium aluminosilicate glasses by high-resolution solid-state Si-29 and Al-27 magic angle spinning nuclear magnetic-resonance. Phys. Chem. Glasses 1985, $26(5), 157-165$. 
(41) Engelhardt, G.; Michel, D., High-resolution solid-state NMR of silicates and zeolites. Wiley: Chichester, 1987.

(42) Brauer, D. S.; Karpukhina, N.; Law, R. V.; Hill, R. G., Structure of fluoride-containing bioactive glasses. J. Mater. Chem. 2009, 19 (31), 5629-5636.

(43) Fuji, E.; Kawabata, K.; Yoshimatsu, H.; Hayakawa, S.; Tsuru, K.; Osaka, A., Structure and biomineralization of calcium silicate glasses containing fluoride ions. J. Ceram. Soc. Japan 2003, $111(10), 762-766$.

(44) Huang, S.; Ingber, D. E., The structural and mechanical complexity of cell-growth control. Nat. Cell Biol. 1999, 1 (5), E131-138.

\section{Graphical Abstract}

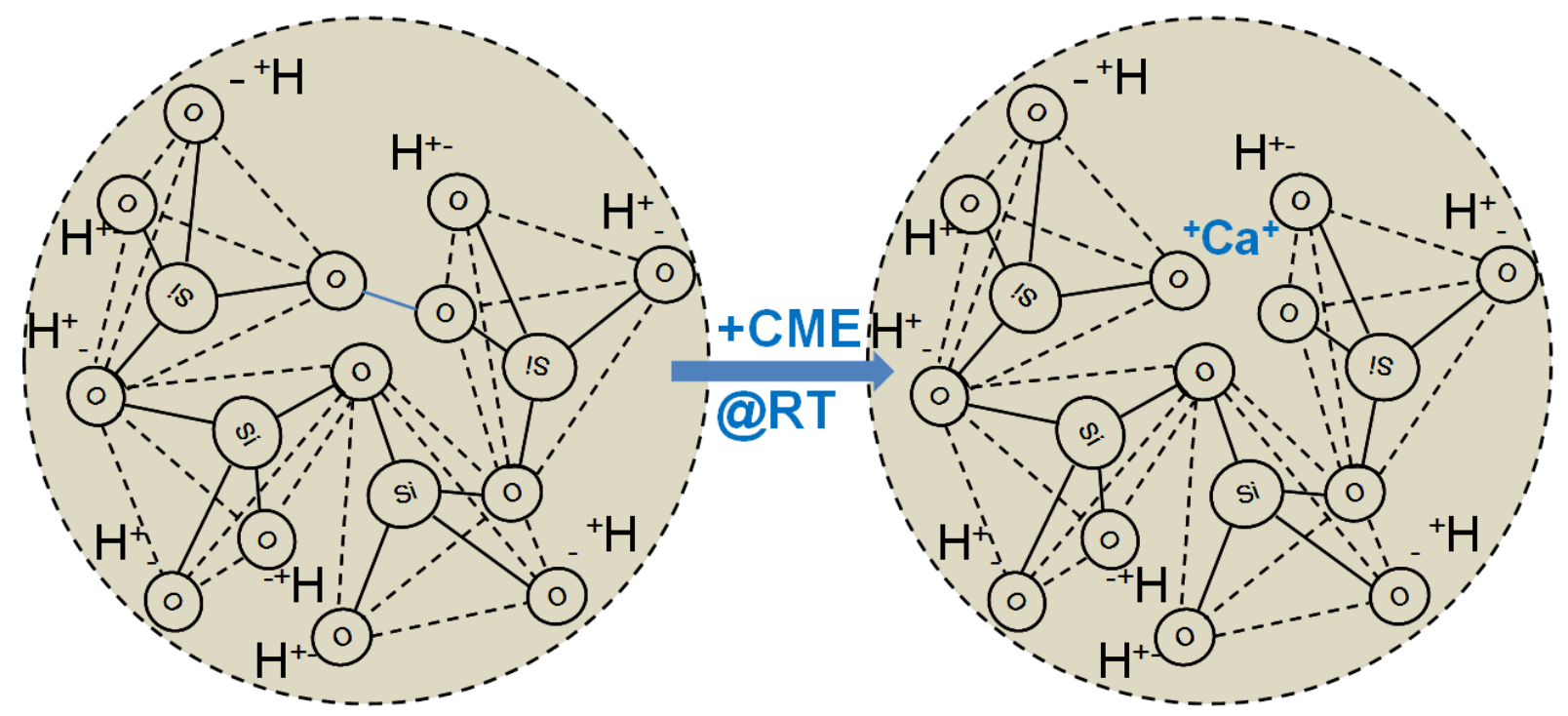

Schematic illustrating that calcium can be incorporated into the sol-gel silica network at room temperature if calcium methoxyethoxide $(\mathrm{CME})$ is used as the calcium precursor. Bridging silicon-oxygen bonds are broken to incorporate the calcium. When calcium salts are used, the temperature must be raised to $>400{ }^{\circ} \mathrm{C}$ for calcium incorporation to occur. The results are very important for sol-gel hybrid synthesis and for improvement of homogeneity in sol-gel glasses. 